NBER WORKING PAPER SERIES

\title{
DO PUBLIC FIRMS RESPOND TO INVESTMENT OPPORTUNITIES MORE THAN PRIVATE FIRMS? THE IMPACT OF INITIAL FIRM QUALITY
}

\author{
Vojislav Maksimovic \\ Gordon M. Phillips \\ Liu Yang \\ Working Paper 24104 \\ http://www.nber.org/papers/w24104 \\ NATIONAL BUREAU OF ECONOMIC RESEARCH \\ 1050 Massachusetts Avenue \\ Cambridge, MA 02138 \\ December 2017
}

Vojislav Maksimovic is from University of Maryland and can be reached at vmax@ rhsmith.umd.edu. Gordon Phillips is from Tuck School of Business at Dartmouth and NBER and can be reached at gordon.m.phillips@tuck.dartmouth.edu. Liu Yang is from University of Maryland and can be reached at lyang@ rhsmith.umd.edu. We thank Ian Appel and seminar participants at the University of Alberta Frontier of Finance Conference, University of British Columbia, Dartmouth College, Hong Kong University, Nanyang Technological University, Purdue University, Singapore Management University, Huazhong University of Technology, SUNY Buffalo, University of Maryland and the University of Oregon for helpful comments. Any opinions and conclusions expressed herein are those of the author(s) and do not necessarily represent the views of the U.S. Census Bureau. All results have been reviewed to ensure that no confidential information is disclosed. The views expressed herein are those of the authors and do not necessarily reflect the views of the National Bureau of Economic Research.

NBER working papers are circulated for discussion and comment purposes. They have not been peer-reviewed or been subject to the review by the NBER Board of Directors that accompanies official NBER publications.

(C) 2017 by Vojislav Maksimovic, Gordon M. Phillips, and Liu Yang. All rights reserved. Short sections of text, not to exceed two paragraphs, may be quoted without explicit permission provided that full credit, including $\odot$ notice, is given to the source. 
Do Public Firms Respond to Investment Opportunities More than Private Firms? The Impact of Initial Firm Quality Vojislav Maksimovic, Gordon M. Phillips, and Liu Yang NBER Working Paper No. 24104

December 2017

JEL No. G3,G32,L2,L20,L22,L25,L26

\begin{abstract}
Using U.S. Census data, we track firms at birth and compare the growth pattern of IPO firms and their matched always-private counterparts over their life cycle. Firms that are larger at birth with faster initial growth are more likely to attain a larger size and to subsequently go public. We estimate a model to predict the propensity to become public ("public quality") using initial conditions. Firms in the top percentile of public quality grow 29 times larger than the remaining firms fifteen years later if they actually become public and 14 times larger if they stay private, showing a large selection effect for IPO status. Public firms respond more to demand shocks after their IPO and are more productive than their matched private counterparts. This effect is stronger in industries that are capital intensive and dependent on external financing. Overall, initial conditions predict firm growth trajectories, selection into public status and responsiveness to demand shocks. We find no evidence of public market myopia when matching by initial conditions.

Vojislav Maksimovic

R.H. Smith School of Business

University of Maryland

Room 4417, Van Munching Hall

College Park, MD 20742

vmax@ rhsmith.umd.edu

Gordon M. Phillips

Tuck School of Business

Dartmouth College

100 Tuck Hall

Hanover, NH 03755

and NBER

gordon.m.phillips@gmail.com

Liu Yang

Department of Finance

Robert H. Smith School of Business

4420 Van Munching Hall

University of Maryland

College Park, MD 20742-1815

lyang@rhsmith.umd.edu
\end{abstract}




\section{Introduction}

In the United States, most large firms are publicly traded, whereas smaller firms tend to be held privately. Public status comes with several distinct advantages, such as access to public capital markets, and the ability to diversify ownership. ${ }^{1}$ There are also potential costs of public status, including costs of dispersed ownership, misaligned investment and growth incentives, and costs from public market oversight. ${ }^{2}$ Several authors, such as Stein (1989), Froot, Perold, and Stein (1992) as well as the New York Times, ${ }^{3}$ have suggested that misaligned investment and growth incentives have the potential to cause investment distortions in public firms. Recently, Asker, Farre-Mensa and Ljungqvist (2015) argue that misalignment incentives are powerful enough as to induce public firms to respond less than private firms to industry growth opportunities. However, comparing private firms with seemingly similar public firms that have gone public years previously, and are at a different stage of their life-cycle, risks confounding differences in public status with inherent differences in quality between firms. In this paper, we show that firms' initial conditions at birth predict their future growth trajectories and public status, and that controlling for this measure of firm quality, public firms are more, or at least as, responsive to growth opportunities as private firms in subsequent years.

We analyze the growth trajectories and responses to growth opportunities by public and private firms over the first fifteen years after birth. We control for inherent firm quality at the beginning of a firm's life, then match firms that subsequently became public with comparable private firms that stay private throughout. Using confidential data from the Longitudinal Business Database (LBD) maintained by the U.S. Census Bureau, we obtain size, growth, labor productivity and other relevant characteristics for a large sample of firms $(892,000$ firms and 5,952,500 firm-years between 1978 and 2008) starting from their first year, regardless of public and private status.

We then use this data to examine the growth trajectories of the firms, and we address the following questions. How persistent are initial conditions? Do firms that are initially larger and

\footnotetext{
${ }^{1}$ See Ritter and Welch (2002) for an overview of both rational and behavioral rationales for why firms go public and the IPO timing. These theories include life-cycle theories (Zingales (1995) and Chemmanur and Fulghieri (1999) and market-timing theories (Lucas and MacDonald (1990), and Baker and Wurgler (2000).

${ }^{2}$ See, for example, the theoretical models by Holmström (1982), Narayanan (1985), Miller and Rock (1985), Stein (1989), and von Thadden (1995). Suboptimal incentives often involve attempts by managers to misinform their dispersed shareholders, or faulty signals due to mispricing in the public markets. The opposite theoretical view about public markets is given by Edmans (2009). He shows theoretically how increased stock-market liquidity and transient blockholders can increase market efficiency and reduce managerial myopia.

${ }^{3}$ See New York Times, July 6, 2010, Smith and Parentau -“Are Profits Hurting Capitalism?"
} 
more productive remain larger and more competitive later in life? Do the same initial characteristics predict future public status? Controlling for these initial characteristics, does public status predict differential growth, efficiency, and responses to growth opportunities? If so, is the differential effect permanent, or concentrated around a firm's decision to go public? Finally, are any differences between our results and the previous literature attributable to sample selection issues when researchers do not control for initial conditions? We show that previous conclusions that publicly listed firms under-react to investment opportunities are driven by cross-sectional matching and selection issues.

We establish several new findings that highlight the importance of controlling for firm initial conditions and firm selection. First, we show that initial conditions strongly predict future firm size. Firms in the top one percent of initial size in the first year are, on average, 20 times larger fifteen years later compared to the average firm born at the same time. Similarly, firms in the top one percent of first-year growth rate or initial average wage are on average 7.2 and 5.6 times larger after fifteen years, respectively. Thus, firm's initial conditions are highly predicative of future outcomes. This is consistent with the conjecture that entrepreneurial talent is persistent. Strategic and talented entrepreneurs who select growth opportunities that yield profits faster create more viable firms, find it easier to raise capital faster, or some combination thereof.

Second, we show that the same initial firm characteristics that predict growth also predict a firm's propensity to acquire public status through an Initial Public Offering (IPO). One standard deviation increase in initial size, initial wage and first-year growth rate increases the probability of IPO by $300 \%, 250 \%$ and $170 \%$, respectively. Moreover, higher propensity also predicts higher growth. A firm with top one percent propensity to subsequently go public employs, on average, 16 times more employees at age of ten than a an average firm whose propensity to go public is outside the top one percent. Among firms with top one percent propensity, those that actually go public are 29 times larger, whereas those that stay private are only 14 times larger than the remaining firms fifteen years later. This difference can be interpreted as an upper bound on the benefits of public status. ${ }^{4}$ These estimates indicate the large role initial conditions play in predicting firm size over time, and the significant effect of selecting public listing.

Third, when we match firms on initial conditions and compare outcomes of public firms and private firms around the times of the IPOs, we find a distinctive pattern. The IPO firms grow faster

\footnotetext{
${ }^{4}$ The difference of 12 times is explained by the benefits of public status, differences in initial quality not observed by us, and events, such as an unexpectedly good outcome of an R\&D program, that may have occurred prior to deciding to go public.
} 
prior to the IPO, and in the first five years after the IPO. However, their growth rate subsequently converges to that of always-private firms five years the IPO. This result is consistent with the notion that the IPO firms are of higher quality. They initially have a growth spurt until reaching their optimal size, and their growth afterwards converges back to the economy average. The transition from private status occurs on average around midway through the firm's high growth trajectory.

Fourth, in the five-year period after the IPO, publicly listed firms react more positively to product market growth opportunities than matched private firms. As with growth, this advantage dissipates over time but does not reverse.

Fifth, we show that during the period of high responsiveness to growth opportunities (first five years after the IPO), the labor productivity of listed firms is higher than or equal to that of matched always-private firms. This is consistent with efficient growth of public firms observed in this interval, after which public firms attain the efficient scale based on their characteristics. Further growth and efficiency from that point are not statistically different from that of always-private firms. Additionally, we show that the closure rates of public firms are lower than that of private firms. Thus, public firms do not attain their higher growth by following riskier growth strategies. ${ }^{5}$ In addition, we observe similar differences in closure rates for firms that became public on or off the IPO waves.

Sixth, we show that public firms' greater sensitivity to growth opportunities holds both when we consider firms' total growth including acquisitions, and when we measure only the growth of firms' original establishments. Thus, the greater responsiveness of public firms does not rely exclusively on their greater participation in the market for assets. We also show that the differential responses to growth opportunities of public firms are greater in industries that rely more on external financing. Public firms in more financially dependent industries grow faster in periods when financing costs are high, which suggests that public status gives firms better access to financial markets when money is tight.

We show that the previous finding that publicly listed firms underinvest in response to product market opportunities (Asker, Farre-Mensa and Ljungqvist (2015)) likely arises because of crosssectional matching of mature firms. We show using Census data that cross-sectional matching leads

\footnotetext{
5 The firms in Jovanovic (1982) exhibit similar dynamics. In that model firms initially do not know their productivity. As their productivity is revealed in the market place, the more efficient firms grow faster. Our data shows, however, that early characteristics are informative of quality and predict future growth. However, since there is residual uncertainty about quality and growth opportunities, similar dynamics arise.
} 
to adverse selection whereby very successful private firms are matched with under-performing public firms. ${ }^{6}$ Firms with very high productivity in their early life grow aggressively beyond their initial size and have a high probability of going public. As a result, very successful public firms are much bigger in size, making it difficult to find size-matched private firms. We show that, in a given year, a sizable sample of very large and efficient mature public firms cannot be crosssectionally matched to private firms. At the same time, unsuccessful public firms on a downward path are likely to be matched to more successful private firms with an upward trajectory. Examining a cross-sectionally matched sample, we find that the lower responsiveness underinvestment of public firms relative to private firms is mostly driven by old, mature public firms. Thus, the finding in Asker et al. that public firms respond less robustly to growth opportunities than matched private firms can be explained by the timing of the match, and the inability to find private matches in cross section for large, very successful public firms.

We perform several tests to address potential concerns with our comparison between public and private firms. First, unobservable firm characteristics may generate unmeasurable differences between IPO and always-private firms in our matched sample. To further clarify the selection effect, we examine firms with Venture Capital (VC) investments earlier in their life. VC investors may have additional information about the firm, and VC sponsorship can serve as a signal for firm quality. We show that IPO firms that are supported by VC earlier in life exhibit even greater responsiveness to demand shocks following their IPO. This finding is consistent with firms with higher quality and stronger initial conditions selecting to move into public status. Second, since IPO and acquisition are the two most common exit strategies for successful private firms, one potential concern is that the differences we observe can be driven by acquisition of successful private firms by public firms. These successful private firms thus exit the sample, which creates downward bias for the matching sample. We show that while initially matched private firms that are subsequently acquired by public firms also grow faster before acquisition than matched firms that remain private, they do not exhibit the same higher sensitivity to growth opportunities over time as firms that go public. Thus, the effects we identify are specific to firms that go public, and are not driven by sample attrition due to acquisitions.

All the results above hold in both specifications when we split into different time periods or control for firm-cohort-period fixed effects. First, we estimate the model in three time periods

\footnotetext{
${ }^{6}$ The summary statistics in Asker, Farre-Mensa and Ljungqvist also show matched public firms decrease in performance (average ROA $=-2.8 \%$ ) versus the full sample of public firms $(\mathrm{ROA}=6.4 \%)$ while the reverse is true for the ROA of matched private firms $(\mathrm{ROA}=11.1 \%)$ versus the full sample of private firms $(\mathrm{ROA}=-11.8 \%)$.
} 
(before the IPO, first five years after the IPO, and five years after the IPO) in order to examine the effect of public status on growth over time. Second, we define a firm-cohort-period fixed effect for each cohort of public firm and its matching private firms, and for each of the three stages of cohort's life-cycle (before IPO, first five years after the IPO, and fiver years after the IPO). This specification allows us to follow cohorts based on initial match over time and control for shocks that affect firms of the same age in each industry. In addition, the post-IPO patterns are also robust to alternative matching at IPO-time as well our matches at birth.

Overall, our results indicate that firm quality is observable very early in firm's life and that its effect is persistent. Higher quality firms go public and they attain larger size. A significant part of size differential between samples of public and private firms is predictable from initial conditions. When matched by initial quality, the growth path of firms that become public diverges from that of always-private firms both before and after the IPO. For a period after the IPO, public firms grow faster and are more responsive to growth opportunities. Predictions of firm size based on initial conditions suggest a lower bound of $49 \%$ of differences in firm size at year 15 due to initial conditions and the remaining $51 \%$ of differences in firm size due to the benefits of public status or unobserved initial differences in quality or luck.

We find little evidence of inefficient growth for public firms. Public firms maintain higher efficiency during high growth periods. The most important differences between outcomes of birthmatched public and private firms occur around the time of the IPO. While some of the difference is due to the increased access to financial markets, we cannot rule out the possibility unobserved selection effects also play a role. Our results also suggest that measurements of initial firm quality may provide an exogenous quality index in other empirical work in corporate finance where researchers need to match firms for quality.

We argue that there is also a strong "foundation effect" in which the entrepreneur's ability is embodied in the firm's structure and influences the exploitation of future growth opportunities in the long run. ${ }^{7}$ Thus, our paper also relates to the literature that traces the effects of managerial characteristics on firm performance. Bertrand and Schoar (2003), Cronqvist, Makhika and Yonker (2012), and Benmelech and Frydman (2015), among others, trace the connection between the personal characteristics of managers and firm decisions.

\footnotetext{
${ }^{7}$ Ayyagari et. al. (2017) investigate how the interaction between firm characteristics at formation and institutions in a developing country predicts outcomes.
} 
Our paper also draws on the literature on decisions to go public. Researchers have both analyzed the trade-offs between public and private status (e.g., Bhattacharya and Ritter (1993), Chemmanur and Fulghieri (1999), Maksimovic and Pichler (2001)) and the benefits to the entrepreneurial firm of sale to public investors or to strategic acquirers (e.g., Bayar and Chemmanur (2010), Chemmanur and He (2011), Gao, Ritter and Zhou (2013), and Chemmanur, He, and Nandy (2010)). These papers focus on product market, and study how information flow and strategic interactions determine the firm's value to outside investors and potential competitors. By contrast, we focus on how a firm's initial characteristics, as perceived the founding team and initial investors, contain information that is predictive of the firm's future value and growth, and how the subsequent transition from private to public status affects the firm's responses to growth opportunities.

We contribute to the research that examines real side differences of public and private firms. Brav (2009) finds that private firms have lower investment rates than public firms in a sample of British firms. Gilje and Taillard (2016) show that relative to private firms, public firms in the gas industry are more responsive to investment opportunities. Lyandres, Marchica, Michaely, and Mura (2013) examine how private and public firms' owners' diversification differentially impacts firm investment. Maksimovic, Phillips and Yang (2013) examine differences between public and private firms in mergers and acquisitions, and Bernstein (2015) examines how public and private firms differ in innovation after their IPOs. Gao and Li (2013) examine differences in CEO pay by public status and find that public firms have higher pay sensitivity than private firms to accounting performance. Phillips and Sertsios (2017) examine public and private firms in the medical device industry and find that public firms have higher financing responses and develop more new products than private firms.

Our paper is also related to Lemmon, Roberts and Zender (2008) who argue that there are persistent firm-specific effects that influence firm capital structures among public firms over time, and that this persistence exists for IPO firms prior to going public. We show that characteristics that predict firm growth trajectories and responsiveness to growth opportunities are set early after firm formation. These characteristics are consistent with the models of entrepreneurship by Lucas (1978) and others.

We organize the rest of this paper as follows. Section II describes our data. Section III motivates our study by highlighting the role of initial conditions. Section IV predicts public status using initial conditions. Section V presents our main results comparing birth-matched public and 
private firms on growth, efficiency and survival. Section VI further explores the effect of public status on growth related to investment type and financial dependence. Section VII uses a crosssectionally matched sample of public and private firms to show issues with ex post matching. Section VIII concludes.

\section{Data}

We use data from the Longitudinal Business Database (LBD), ${ }^{8}$ maintained by the Center for Economic Studies (CES) at the Bureau of the Census to track growth for both public and private firms. The LBD covers non-farm establishments with paid employees in all industries and all states in the U.S. beginning in 1976. It has about 8.5 million records in 2012 and contains information on ownership, location, status (active or inactive), industry, employment and total payroll on the establishment level. In their review of PSED data, Hurst and Pugsley (2011) conclude that "most individuals who start a small business have little desire or expectation to grow their business beyond a few employees." To avoid confounding our results with these firms, we follow the common practice of dropping very small firms with less than four employees. For firms born after 1976, the first year of the LBD, we identify the birth year of the firm as the first year that firm identifier appears in the data. Since the LBD keeps separate identifiers for the firm and the establishments, for new establishments added to a firm, we can separate organic growth from acquisitions. $^{9}$

We use the IPO data provided by Jay Ritter's website. ${ }^{10}$ We collect information on IPO firms from 1981 to 2005 including company name, CRSP Permanent ID, offer date, ticker at the offering, founding date and VC funding status. We then use the existing bridge file created by the CES staff to identify the IPO firms in the LBD. To construct the bridge file, firms are matched by employer identification number (EIN) and name in each year from 1980 to $2005 .^{11}$ To ensure the accuracy of the match, we impose several additional restrictions. We exclude firms from the sample if the founding date provided by Jay Ritter differs from the LBD initial year by more than five years (in both directions) or the difference in employment in the IPO year is more than $25 \%$ between the

\footnotetext{
${ }^{8}$ The LBD reports a snap shot of firm conditions on March 12 every year and contains all firms that have at least one paid employee.

${ }^{9}$ For more information about LBD, see https://www.census.gov/ces/pdf/CES-WP-02-17.pdf.

${ }^{10}$ See Jay Ritter's website at https://site.warrington.ufl.edu/ritter/ipo-data/

${ }^{11}$ Not all IPO firms during this period are matched through the bridge file. We lost about one third of the sample due to missing Census' firm id in the bridge file.
} 
COMPUSTAT and the LBD. These additional criterial eliminate $20 \%$ of the matched IPO firms. In order to guard against including leveraged buyouts, we also eliminate IPOs of firms that were previously public. Our initial matched sample consists of 2,900 IPO firms with initial conditions identified in the LBD, giving us a match rate of $48 \%$.

Compared to the overall sample, our matched IPO firms are smaller and younger at the IPO compared to Ritter's IPO sample. ${ }^{12}$ However, they have very similar distribution across industries and over IPO years compared to unmatched IPO firms. In unreported tables, we also find that the matched and unmatched IPO firms experience similar growth rate in sales post IPO using COMPUSTAT data.

Since the LBD does not differentiate new firm creation from spinoffs and those from organic birth, also we eliminate firms that are formed in their first year with establishments that existed before and firms with more than 200 employees reported at birth in the LBD. These last criteria eliminate $29 \%$ of the matched IPO firms.

To predict the decision of going public based on initial conditions, we create a birth sample that contains all firms in the LBD born after 1978 with fewer than 200 employees in the first year reported in the LBD, using a similar screen as we use for the IPO firms. We also eliminate industryyears (based on 3-digit SIC codes) that yield no IPO firms. We then specify a dummy variable that equals to one if a firm is in our matched IPO sample and zero otherwise. We excluded the unmatched IPO firms. The growth rates between two samples fifteen years after IPO are not significantly different.

Our final sample has about 892,000 firm births (given we only include industry-years in which there was an IPO) and the probability of going public is about $0.2 \%$, with variation over time and industries using industries with at least one IPO. We identify the age at the IPO as the difference between the offering date and the birth year reported by the LBD. We use the birth sample to run our regressions to predict the probability of going public using initial birth conditions. We then construct a panel data by tracking firms in the birth sample over time for up to 15 years. Our panel data has approximately 5.9 million firm-year observations.

For cross-sectional matching, we use the same bridge file constructed by Census staff to identify all public firms in the LBD during the entire sample.

\footnotetext{
${ }^{12}$ The match rate is higher for single-establishment firms and lower for firms with multiple establishments.
} 


\section{Initial Conditions and the Lifecycle of the Firm}

In this section, we provide some initial motivating evidence using a comprehensive sample of 892,000 post-1978 firm births from the Census Bureau. Figure 1 shows that initial size at the end of the first year already differs between private and subsequently public firms. This difference grows over time - 15 years after their birth, public firms are substantially larger. The increase in observed differences in size between public and private firms in Figure 1 can reflect the difference in initial firm quality and also treatment effects from differential access to financing.

\section{[Insert Figure 1 Here]}

Figure 2 provides some motivating evidence that initial conditions are persistent and related to long-run firm growth. We sort firms by their initial conditions including size and wage in the first year we observe them, and the first full-year employment growth, which occurs between the first and second year when firm appears in the LBD. ${ }^{13}$

For each variable, we separate firms that are in the top one percent of their distribution from the rest of the firms from the same industry-year cohort. Then we compare the average employment size from these two groups going forward - not taking into account whether these firms are public or not. Figure 2 shows that firms that are born at larger size, paying higher wages, and having high initial growth continue to grow faster for fifteen years post-birth. The observed persistence in initial conditions is consistent with the idea that the entrepreneurs have different skills and those skills influence long-run firm growth.

\section{[Insert Figure 2 Here]}

In subsequent sections we break up our analysis into four parts. First, we examine whether firms that are larger and more productive immediately after birth are on a higher long-run growth trajectory than initially smaller and less productive firms, and whether the same initial conditions also predict future public status. We also derive a propensity score for measure the "public quality" of all young firms using initial size, growth and productivity. Second, we create a matching sample of IPO firms and private firms based on the predicted "public quality". Third, we show that firms

\footnotetext{
${ }^{13}$ The LBD is created using information collected on March 12 every year. For firms born after March 12, the first time it appears would be subsequent year. Thus, the newly-born firms we identify can be up to 11 months old.
} 
that in fact do become public show a distinctive growth trajectory pre-and post- IPO that differs from those of firms with the same initial propensity but remain always-private. We perform a variety of robustness checks on our main results. Last, we reconcile our findings with previous findings that public firm underinvest in response to product market opportunities.

In Table 1 we examine whether firms' initial characteristics predict future firm size. We measure firm size using employment five, ten, or fifteen years after birth, respectively. Initial employment measures the number of full-time employees in the first year reported by firm. Initial wage is calculated as the average wage paid by firm in the first year. Initial growth measures the growth of employment from the first to the second year. We include year and industry fixed effects in all specifications and cluster error by industry-year. Industries are defined using 3-digit SIC level. Table 1 shows that firms' initial conditions predict future growth over all three horizons. This suggests that a component of the firm's quality is observable early in the life of the firm and persists for up to 10-15 years. This observable characteristic is perceived by entrepreneurs and early financial backers of the firm, while the firm is still private. We next investigate whether these initial indicators of firm quality also predict the firm's decision to go public. ${ }^{14}$

\section{[Insert Table 1 Here]}

\section{Predicting Public Status}

Since firms select to become public, it is reasonable to infer that going public provides value to the firm, or at least to the founders and initial investors. Public firms have the ability to raise equity in public markets. The enhanced access to capital markets helps investors to achieve optimal diversification and allows the firm to raise capital at lower cost. Access to publicly traded equity also helps the firm finance acquisitions with stock and reward employees with traded stock. On the other hand, dispersed ownership in public firms may lead to unresolved agency conflicts and investment myopia (e.g., Stein (1988)). Edmans (2009) shows theoretically how large blockholders in public firms can attenuate managerial myopia through their trading and how liquidity and transient shareholdings can increase public firm's investment by increasing market

\footnotetext{
${ }^{14}$ It is also possible that all firms are initially of the same quality, and that some firms were luckier than others in getting more resources at the very beginning. If so, the interpretation of our results would change slightly, to show that initial luck in obtaining financing affects firms' trajectories in predictable ways over the long term. We do not emphasize this interpretation, however, given the results in Howell (2016) that show that windfalls of capital do not alter firms' trajectories in this way.
} 
efficiency. The net advantage of public status thus depends on firm size, as the fixed costs of attaining and maintaining public status, and the comparative advantage of access to public markets, is likely to make public status more attractive to larger firms. Our focus in this paper is on the selection of which firms decide to become public and whether public status has, on balance, a positive or a negative effect on the firm's ability to respond to demand shocks. To establish this, we also investigate productivity and survival of birth-matched public and always-private firms.

Our central hypothesis is that given inherent talent, the benefits of public status are greater for firms on a fast growth trajectory that expect to engage in greater financing and investment. Thus, firms which select to become public are likely to be of higher quality, and they will respond more strongly to growth opportunities. In order to evaluate the effects of public status we must control for the differences between the firms that select to become public and the firms that do not.

We first begin by predicting which firms will become publicly traded later in life. Defining $Y_{\text {it }}$ to be an indicator variable for public status with $\mathrm{Y}_{\mathrm{it}}=1$ for publicly traded firms and 0 for private firms, we model the firm's decision to go public as follows:

$$
\begin{array}{rlrl}
\mathrm{Y}_{\text {it }} & =0 & & \text { if } \quad \mathrm{V}(\mathrm{P} \mid \text { Talent, Costs })<0, \\
=1 & \text { if } \quad \mathrm{V}(\mathrm{P} \mid \text { Talent, Costs })>0 .
\end{array}
$$

Here V(P | Talent, Costs) is the value of becoming public given the firm's industry, its underlying talent and its costs of becoming public and maintaining public status. We thus regress the public market indicator on a firm's inherent initial talent and industry conditions. To capture the inherent talent we use birth conditions which include initial employment (in log), initial average wage (in $\log$ ), and the first annual growth rate for which we have data. As Figure 2 shows, these initial conditions are very persistent over time. We also include squared terms of these variables to account for non-linearity. We estimate this equation using a linear probability model. ${ }^{15}$

In a second specification, we also include industry control variables that capture industry growth, percentage of firms engaged in mergers and acquisitions, and percentage of small firms in the industry. The M\&A rate proxies for the time-varying incentive to go public in order to facilitate expansion through acquisitions. ${ }^{16}$ Small firms are defined as firms with less than 50 employees

\footnotetext{
${ }^{15}$ LPM does as good a job approximating marginal effects as a non-linear model as a marginal effect is just a slope and is less subject distributional problems than a logit or probit model as emphasized by Angrist and Pischke (2009) in Chapter 3.4.2.

${ }^{16}$ Merger-motivated IPOs are studied in Celikyurt, Sevilir, and Shivdasani (2010) and Hovakimian and Hutton (2010).
} 
following the Department of Commerce categories. Firms may have less incentive to go public in an industry that is dominated by small firms in which they can reach optimal scale without raising much funds externally.

This specification enables us to test whether initial conditions predict the tendency to go public later in life. Specifically, it enables us to test whether larger and faster growing young firms become public. The former hypothesis is motivated by Lucas (1978) who predicts that initially larger firms are led by more talented entrepreneurs, and the latter by Jovanovic (1982) where, controlling for size, young firms perceived to be of higher quality grow faster. In addition, this specification also yields a "public quality" index based on the propensity of becoming public. We can use this index to control for initial observable firm characteristics when comparing subsequent outcomes between firms that become public and those that stay private. ${ }^{17}$ Since this index is calculated using firms' initial conditions, it does not rest on the timing of the IPO and therefore is not influenced by changes in growth opportunities at the time of the IPO and by IPO waves (Pastor and Veronesi (2003)), which we verify empirically below. Table 2 presents the results.

\section{[Insert Table 2 Here]}

Firms that are initially larger and pay higher wages at birth are more likely to be public later. One standard deviation increase in initial size and initial wage leads to $300 \%$ and $250 \%$ increase in the predicted public quality index from the mean, respectively. Firms with higher first-year growth also have higher public quality index. One standard deviation increase in growth rate leads to $170 \%$ increase in the probability of becoming public from the mean. The industry variables, industry growth, percentage $M \& A$ are both strongly significantly positive. Firms in industries with high growth and where there are a high frequency of M\&A are likely to be public, consistent with public firms find it advantageous to use external capital to help grow and to use equity to buy other firms.

\section{Public Status and Firm Growth}

\section{A. Lower and Upper Bounds for Selection and Treatment}

Using the predicted public quality index from Column 1 in Table 2, we now examine graphically how initial conditions relate to firm growth over time.

\footnotetext{
${ }^{17}$ This parallels for firm quality the indices used to measure financial constraints, for example Kaplan and Zingales (1998) and Hoberg and Maksimovic (2015).
} 


\section{[Insert Figure 3 Here]}

In Figure 3 we examine the firms - both eventually public and always private - that are in the top $1 \%$ of the predicted public quality index and graph their growth in their number of employees over time. Several results can be seen in the Figure 3. First, both always private and eventually public firms that are in the top $1 \%$ of the predicted public quality index become sharply larger than other firms. Fifteen years later, firms that started out in the top one percent of the public quality index have 955 employees on average, more than 16 times bigger than the average for the rest of the distribution. Moreover, private firms in the top $1 \%$ have 831 employees by year fifteen compared to 59 employees on average for all other firms - 14 times larger. This measures the lower bound for the selection effect.

Second, firms in the top $1 \%$ of the predicted public index that do go public have an average of 1,696 employees and are 29 times bigger than the average firm outside of the top $1 \%$. The difference between this size difference of 29 times and the previous private size difference of 14 times can be interpreted as the upper bound of the treatment effect, as part of this difference may still be due to selection based on unmeasured attributes.

We investigate the predictive power of our public quality index for high quality firms in a regression setting in Table 3. The dependent variable is the annual employment growth. We define high public quality index, HPI, equal to one if the estimated public quality index based on initial conditions (estimated in Table 2 Column 2) is above the $99^{\text {th }}$ percentile of all firms at birth and zero otherwise. We interact HPI with a measure of industry demand and a measure of the tightness of access to financing. Our measure of industry level (at 3-digit SIC) demand, DS, is the demand shock constructed based on changes of shipment from vertical industries. We focus on positive demand shocks as we wish to measure how firms respond to increases in growth opportunities. Our measure of liquidity, CS, measures the credit spread for the year between A3 and Baa corporate bonds. Both measures have been widely used and are described in detail in Maksimovic, Phillips, and Yang (2013). We control for industry-year fixed effects in all regressions and cluster the error at the industry-year level.

\section{[Insert Table 3 Here]}

Column (1) shows that firms with high public quality firms grow faster than other firms, most specifically in years when demand increases in their industry. The coefficient of the interaction 
between HPI and liquidity in the economy is insignificant, suggesting that firms with high public quality index do not grow faster at times of higher credit spreads. This is not surprising since the majority of the firms in the HPI category stay private throughout the sample period. In column (2) we restrict the sample to firms that never go public, and again find that firms that a have a high public quality index grow differentially faster when their industry receives a positive demand shock. It further confirms that the index we construct captures firm quality. In columns (3) to (6) we again examine all firms, and split the sample by firm age. We find that the predictive power of the public quality index is highest in the firm's first five years.

In summary, the figures and tables above present a consistent relation between a firm's initial characteristics and its subsequent growth. In particular, regardless of whether a firm goes public or stays private, firms that are initially larger, grow faster, and are more productive respond more strongly to industry growth opportunities. This effect is strongest early in the firm's life-cycle. We next investigate whether the firms that go public respond differently to growth and financing opportunities than private firms with similar initial characteristics.

\section{B. Matching IPO Firms and Private Firms}

Having established the finding that better initial quality firms with are more likely to subsequently grow faster and become public, we first match IPO firms with always-private firms at birth based on initial quality For each IPO firm in our sample, we select up to 5 closest-matches from private firms from the same industry and birth year based on the predicted public quality index (using Column 1 in Table 2). We also require the matched private firms to survive at least up to the IPO year and the relative size of the matched private firm to the IPO firm is within the range of $(0.5,2)$. We exclude IPO firms with fewer than three matches to obtain common support. Our results are robust if we restrict to exactly five matches. Our final sample has about 1,600 IPO firms and about 8,000 matched private firms. Table 4 provides summary statistics comparing IPO firms with matched and unmatched private firms.

\section{[Insert Table 4 Here]}

Table 4 shows that IPO firms and matched private firms have very similar predicted public quality index. The Kolmogorov-Smirnov test for an equal distribution has a p-value of 0.51 , suggesting that the distribution of the predicted public quality index between public and matched private firms are not significantly different. Both eventually public and matched private firms are 
much more likely to go public later in life - the estimated probability of being public is about 40 times higher for these two groups compared to the unmatched private firms. We also present statistics for the number of employees, the initial wage in thousands of dollars, and the initial yearly growth rate - both for public firms and matched and unmatched private firms. IPO firms and matched private firms are also similar in size and the initial growth rate in their initial years although private matched firms tend to have higher average wage. In contrast, there is a stark difference between matched and unmatched private firms. Unmatched private firms are much smaller at birth, have lower wages, and experience a much slower initial growth rate compared to matched private firms. Table 4 highlights the selection effect in public status and emphasizes the need for controlling for firm quality when comparing the difference between public and private firms.

Figure 4 presents the distribution density in size for IPO firms and their matched private counterparts. The two groups have similar size at birth, a result of matching, but deviate over time. At the IPO, the public firms are already bigger than the matched private firms. The difference keeps growing 5 and 10-year following the IPO.

\section{[Insert Figure 4 Here]}

As a robustness check, we also create an alternative matched sample based on initial conditions that does not rely on our index of public quality. There, for each IPO firm, we select five private firms based on initial size, initial wage, and first-year growth rate using the nearest neighbor matching, not using the index based match. All of our subsequent results are qualitatively the same.

\section{Responses to Growth Opportunities}

We now examine whether and how IPO firms differ from their matched counterparts in their responsiveness to demand shocks compared to their matched private counterparts. We estimate the following basic specification using annual data in the sample of IPO firms and their matched always-private firms:

$$
\begin{aligned}
\text { Growth }=\beta_{0} & +\beta_{1} P u b+\beta_{2} D S+\beta_{3}(D S \times P u b)+\beta_{4} C S+\beta_{5}(C S \times P u b) \\
& +\gamma \text { control variables }
\end{aligned}
$$

where $P u b$ is an indicator variable for actual public status. Growth is measured in employment winsorized at one percent on both ends. As before, we use changes in shipments in downstream 
industries to capture exogenous shocks to industry demand. Since our hypothesis is that being public facilitates response to changes in industry demand that require expansion of the firm scale, we focus on the positive part of the industry demand shocks, DS. All of our results are robust when we use industry demand shocks in both directions.

Public and private firms may also be affected differently by financial market shocks. Public firms can access public financial markets, especially for long-term capital, at more favorable or easier terms while private firms rely more on short-term financing from financial intermediaries (Brav (2009)). We thus examine whether credit conditions in the debt markets impact public firm growth and thus include a credit spread variable (CS). Lown, Morgan, and Rohatgi (2000) find that credit spreads are strongly correlated with the tightening of liquidity measured from the Federal Reserve Senior Loan Officer (SLO) survey. We calculate credit spread as the difference in interest rate between the $\mathrm{A} 3$ and Baa rated-bonds.

We control for a variety of firm characteristics. $\log (\mathrm{Emp})$ is the logarithm of firm employment. $\log$ (Wage) is the logarithm of firm's average wage. Age measures the firm's age following birth. All variables are lagged. Our results are robust when we exclude firm characteristics.

Figure 5 presents growth rates of IPO firms around IPO. Regardless of firm age at IPO, there is one common pattern. IPO firms grow faster prior to the IPO, and in the first five years after the IPO. The growth rate subsequently converges to the economy average. In comparison, the average growth rate of all private firms is close to zero. Given the observed difference in growth over time, in all of our later analysis, we estimate our regressions separately in three time periods - prior to the IPO, first five years after the IPO, and five years after the IPO.

\section{[Insert Figure 5 Here]}

Thus, for each IPO firm, we break up the time interval to three separate periods, $(-5,-1),(1,5)$ and $(6,10)$ where 0 denotes the IPO year, to examine the event windows around the IPO. The first period tracks firms in their private, pre-IPO period, and the other two windows track the early and late public years respectively. We follow the same time frame and use the IPO year of their public match to define event windows for matched private firms.

In Table 5, columns (1) - (4), we estimate equation (1) using all firm-years and then separately for each of the three sub-periods. The coefficient $\beta_{1}$ yields the differential growth rates for firms that become public. The coefficient $\beta_{3}$ and $\beta_{5}$ enable us to estimate the difference in growth sensitivity to demand shocks and financial market shocks, respectively, between public and private 
firms. Similar specifications are used in Gilje and Taillard (2016) and Asker, Farre-Mensa and Ljungqvist (2015). The interpretation of these coefficients differs across event windows. Since the IPO decision occurs at time 0 and is likely to be based on performance in the immediately prior period, coefficients estimated over the period $(-5,-1)$ compare the performance of firms ultimately selected to become public with firms with similar conditions at birth but did not become public prior to IPO. The window $(1,5)$ describes early IPO years for public firms. Since decisions (to become public) have already been made, any excess performance over this period does not cause an IPO. Instead, it will describe the possible effects of recently acquired public status, but will be an upper bound for any treatment effect as part of the difference in performance may be due to quality differences we do not measure. Over the window $(6,10)$, excess performance, if any, is more likely to reflect steady state effects.

We define industry by 3-digit SIC and include industry-year fixed effects. Since $D S$ varies by industry-year and CS is an annual measure, the main effects of both variables drop out after including industry-year fixed effects.

In columns (5) and (6), we adopt a fixed effect specification. We treat each firm in our IPO sample and its matching always-private firms as a separate cohort. For each cohort, we further separate firm-years into three periods, namely up to five years prior to the IPO $(-5,0)$, first five years following the IPO $(1,5)$, and six to ten year after the IPO $(6,10)$. Thus, we have $1600 \times 3$ firm-cohort-period fixed effects. This procedure controls for shocks that affect the growth of each IPO firm and the matching always-private firms at different points of their life cycle. Since the matching firms are of the same age and industry as the IPO firms, this fixed effect, in addition to year fixed effects, removes the possibility that the differences are cohort-specific and persist over particular periods of time. ${ }^{18}$ Thus, this fixed effect structure provides for a stringent control of factors that might confound cross-sectional differences in performance between public and private firms. Robust standard errors allow for clustering at the industry-year level are reported in parentheses throughout.

\section{[Insert Table 5 Here]}

\footnotetext{
${ }^{18}$ Our results also hold with conventional firm fixed effects but we use separate cohort effects because these capture possible technological changes in the industry that are specific to IPO firms and their particular cohort.
} 
Column 1 of Table 5 shows that public firms grow faster and are more responsive to growth opportunities, as measures by demand shocks DS. There is also evidence that public firms grow relatively faster in periods when credit spreads are high.

Examining the results broken out by the years surrounding a firm's IPO in columns (2) - (4) we can see some interesting patterns. The public indicator variable is positive and significant for the five years prior to the firm's IPO and the five years after, but becomes insignificant for years greater than five. Examining the interaction of eventual public status with the demand shock, we find that it is in the earlier years (before year five) following the IPO that public firms react more positively to changes in demand than private firms. IPO firms grow $1.7 \%$ more than their private counterparts for every one standard deviation increase in positive demand shock. This result is consistent with public firms growing faster pre-IPO to reach a certain size with internal and private funds and using the funds from their IPO and their access to public markets to better take advantage of industry growth opportunities. However, growth and sensitivity to demand shocks fall back to their private market matched firms after first five years. In an unreported table, when we re-run the specification in Table 5 year by year following year five, we do not find that public firms significantly differ from their private counterparts, either in growth rate or response to demand shocks. The other control variables in the regression show that basic economics holds for these firms. The positive coefficient on wages indicates that firms, perhaps indicating higher human capital grow more. There are negative coefficients on age and employment, consistent with growth slowing down over the firm's life and there being some decreasing returns to scale. We show, in an unreported table, that our results are robust without controls such as size and age.

In columns (5) and (6) we report specifications including firm-cohort-period fixed effects. In column (5) we show that public firms which become public at some point grow faster and are more responsive to growth opportunities, without considering their pre- and post-IPO periods separately. In column (6) we focus on the post-IPO period and split it into years 1 to $5(1,5)$ and years 6 to 10 $(6,10)$ by including two indicator variables, PostIPO_1to5 and PostIPO_5+. It shows that public firms grow faster and respond to growth opportunities more strongly than private firms in the first five years after the IPO. The estimated coefficients have similar magnitude as those reported in column (3). However, the differential effect disappears thereafter, consistent with the specification in column (4).

These results indicate a natural life-cycle process for firms. Firms that become public grow fast for up to five years following the IPO but their growth is similar to their matched private firms 
afterwards. It is worth noting that public firms are of a much larger size at this point. These results are consistent with firms obtaining a larger, optimal firm size after five years post-IPO.

Interactions of $P u b$ x CS provide very limited evidence that public firms benefit differentially from access to financing during periods of low liquidity. Some of these firms may not have credit ratings which may potentially explain the insignificance. In addition, benefits from access to financial markets is likely to be a result of their underlying quality and size, and therefore captured by the fixed effects.

\section{Efficiency of Public Firms}

We have shown that public firms respond more to positive demand shocks in the first five years after their IPO. While these results are suggestive of efficient investment strategy, it is also possible that public firms may over expand beyond their optimal scale given their access to lessexpensive public capital. We now examine efficiency for IPO firms in the post-IPO period, especially during periods when they grow more following a positive demand shock. Ideally we would like to use profits or total factor productivity measures, but those items are only available

for manufacturing firms while the vast majority of the IPO firms during this period are outside of manufacturing industries. Thus we resort to a labor productivity measure based on sales per employee ratio. It is also consistent with our growth measure based on employment. Foster, Haltiwanger, and Krizan (1998) show that sales-employee ratio is highly correlated with total factor productivity in U.S. manufacturing firms.

\section{[Insert Table 6 Here]}

Inspection of Table 6 reveals very little evidence that the higher growth rates and higher responsiveness to growth opportunities of public firms come at the cost of lower labor efficiency. To the contrary, public firms are more efficient when their industry receives a positive demand shock, especially in the first five years after the IPO. The interaction between the public status indicator and demand shock is positive and significant at one percent lever in columns (3) and (6). It indicates that public status helps firms to adapt to changing industry conditions and become more efficient in expansion.

Interestingly, we find that the labor efficiency of public firms increases relative to private firms in years when the financing is more readily available (i.e. credit spread is low) prior to and immediately after IPO. This contrasts with the result in Table 5 that the growth rate of firms is 
unaffected by the credit spread over these life-stages. It suggest that while the growth of early stage public and pre-public firms is not affected by credit spreads, public firms facing low financing costs may be able to invest correspondingly in capital assets to maintain their labor productivity.

\section{E. Survival and Firm Risk}

A natural question to ask is whether the higher growth we have documented for public firms comes at the expense of higher risk. We investigate this question by examining the failure rate of public firms and their matched private counterparts. In Panel A of Table 7, we estimate a Cox Proportional Hazard model - where the hazard is defined as "death". In this model, a negative coefficient indicates a lower chance of death and thus a higher probability of survival.

We identify "death" of a firm as the case in which the firm is out of business and none of its establishments is active. "Death" is thus the closure of all establishments of a particular firm. Since the LBD has different identifiers for firms and for establishments, we can separate acquisitions from plant closures. We do not count cases when a firm ceases to exist and its plants are subsequently acquired and continue to be operated by other firms as "death". Therefore, our definition captures the economic survival rather than the business survival. Since we restrict the matched private firms survive at least to the IPO year, we begin our estimation from the IPO year (year 0).

\section{[Insert Table 7 Here]}

Column (1) of Panel A of Table 7 shows that public firms are more likely to survive. The survival rates are tabulated in Panel B. The difference between public and private firms is more pronounced in early years. Five years after the IPO, $21 \%$ of public firms close, as compared to $32 \%$ for matched private firms. In an unreported table, we also find that public firms are more likely to be acquired than private firms.

One potential concern for breaking out time periods surrounding the IPO is that firms may have timed their public offering in response to financial expected market factors, thereby introducing sub-optimal growth patterns relative to firms which always remain private. For example, firms may choose to grow too fast too early in order to be able to take advantage of anticipated financial market mispricing, as might occur during hot markets. In Columns 2 we show that the effect of public status on survival is not affected whether or not the firm goes public during IPO waves. We 
define IPO waves as years in which the number of IPOs is two standard deviations above the average in our sample period using Ritter's data. ${ }^{19}$

Taken together, Table 5-7 show that public firms are more responsive to industry growth opportunities and that their growth is efficient and does not lead to risker strategies.

\section{F. IPO Firm Growth and VC Investments}

We match our sample of IPO firms with private firms at birth based on observable firm characteristics such as industry, size, wage and initial growth. However, unmeasurable difference may still exist between IPO firms and always-private firms. To provide more evidence on the selection effect, we examine the effect of VC investments on firms' exploitation of growth opportunities. VC investors may have additional information about the firm quality and VC sponsorship can serve as another signal for firm quality. Puri and Zarutskie (2012) show that in their sample VC-financed firms grow faster and outperform matched firms that are not financed by VC. Such an effect may occur both because VCs select higher quality small firms and because they provide mentoring and monitoring services (Bernstein, Giroud, and Townsend (2016)) or because they set up more investor friendly governance structures (Hochberg (2012)).

We use VC-investment information from Ritter's data base to separate public firms into two groups - VC-sponsored (VC) or non-VC-sponsored (Non_VC) to examine the effect of VCsponsorship on the differential growth between public and private firms. Specifically, we estimate the following specification:

$$
\begin{gathered}
\text { Growth }=\beta_{0}+\beta_{1} P u b \times V C+\beta_{2} P u b \times N o n_{-} V C+\beta_{3}(D S \times P u b \times V C) \\
+\beta_{4}\left(D S \times P u b \times N o n_{-} V C\right)+\beta_{5}(C S \times P u b \times V C)+\beta_{6}\left(C S \times P u b \times N o n_{-} V C\right) \\
+\gamma \text { control variables }
\end{gathered}
$$

$\beta_{1}$ and $\beta_{2}$ capture the difference in growth rates between IPO firms in VC- or non-VC sponsored IPO firms and matched private firms, respectively. $\beta_{3}$ and $\beta_{4}$ capture the difference in responsiveness to demand shocks, and $\beta_{5}$ and $\beta_{6}$ capture the difference in responsiveness to financial shocks. As in our main regressions, we control for industry-year fixed effects. Table 8 reports our findings.

[Insert Table 8 Here]

\footnotetext{
${ }^{19}$ We use Ritter's data to define IPO waves so that we can capture all IPOs in a given year.
} 
Both VC and non-VC firms grow faster than matched always-private firms in their pre-IPO period. However, in the period after the IPO, the differential opens up, and VC sponsored pre-IPO firms outperform their matched always-private firms both in growth rates and responsiveness to growth opportunities. The evidence is consistent with VC firms selecting better firms who go public or helping firms before their IPO. The VC backing helps the firms before their IPO and they respond more than private firms to demand shocks.

\section{How and When is Public Status Important?}

\section{A. Internal vs. External Growth}

Table 5 above shows that firms grow faster in the years prior to their IPO and in the first five years post-IPO. This growth may be internal or through acquisitions. We would expect public firms to have an advantage in growth through acquisition through the issuance of shares, as documented by Celikyurt, Sevilir and Shivdasani (2010). We thus examine whether the higher growth of IPO firms arises from acquisitions which are directly facilitated by public status or through expansion of existing operations.

We identify internal (or organic) growth by tracking the growth of establishments that firms had from the very beginning. It includes growth of the firm's existing establishments and from newly built establishments, and excludes additions to the firm that occur through acquisitions. We are able to separate establishments that are newly built from those acquired as Census keeps separate identifiers for firms and establishments. Since acquirers often only keep a portion of the establishments from acquisitions and sell off the rest (Maksimovic, Phillips and Prabhala (2008)), we exclude growth from acquired establishments in all years after the acquisition. Our approach is likely to create a downward bias for estimating internal growth. Since public firms are more likely to engage in acquisitions (Maksimovic, Phillips and Yang (2013)), it would under-estimate internal growth from public firms compared to private counterparts. Table 9 examines internal growth in the matched sample over different time horizon surrounding IPO.

\section{[Insert Table 9 Here]}

Table 9 follows the same structure as that in Table 5. The only difference is that it uses the ratio of internal growth as dependent variable instead of overall growth. Column 1 shows that as for the overall growth, IPO firms also differ significantly in how they exploit growth opportunities using their assets in place, in that they are more responsive to growth opportunities. Interestingly, 
the magnitude for the coefficients on $P u b^{*} D S$ in column 1 is very similar to that reported in Table 5 when we include both internal and external growth -0.295 vs. 0.317 . On the other hand, the estimated coefficient on public status is noticeably smaller than in Table $5-0.053$ vs. 0.089 . These findings suggest that although acquisitions account for an important part of the difference between public and private firms, the greater responsiveness of public firms does not only rely on their greater participation in the market for assets.

As in Table 5, public firms' greater responsiveness to growth occurs mostly in the first five years after the IPO. Another interesting contrast between Tables 5 and 8 is in the growth rates of IPO and private firms. In both tables the growth rates of firms that become public in the pre-IPO period $(-5,-1)$ is higher than that of matched private firms. However, after the IPO there is divergence in overall growth rates and the growth rates of the assets that IPO firms possessed at birth. Specifically, five years after the IPO the growth rate of the public firms' initial assets declines below that of private firms. This result is consistent with the finding that public firms are much more active in acquisition markets than private firms (Maksimovic, Phillips, and Yang (2013), Arikan and Stulz (2016)) and that larger firms grow by acquisition rather than by organic growth (Maksimovic and Phillips (2008)). This finding also suggests that a focus on capital expenditures in comparison of public and private firms' investment patterns may miss important distinctions between these categories of firms.

Column 5 and 6 estimate the model with firm-cohort-period fixed effects, similar to that used in Table 5 and find consistent results.

\section{B. IPO Firm Growth and Acquisition of Private Firms}

Since an IPO and acquisition are the two most common exit strategies for successful private firms (Bayar and Chemmanur (2011)), one potential concern is that the difference we observe can be driven by successful private firms being acquired by other public firms and thus exiting the sample, creating a downward bias for the matching sample. This might occur because private firms in our sample are matched to the public firms at birth. For each public firm, we select up to five matched private firms based on initial conditions and survival up to the IPO year of the reference public firm.

To gain further understanding of this process, we separate matched private firms into three groups based on their acquisition status - never acquired (baseline), acquired by private firms (Prv_Acq_Prv=1), and acquired by public firms (Prv_Acq_Pub=1). We then track growth and 
responsiveness to shocks of each group compared to the baseline. For firms that are subsequently acquired, we exclude firm-years after the acquisition as the establishments then belong to another firm. Table 10 reports our findings.

\section{[Insert Table 10 Here]}

In Table 10 we analyze the growth trajectories of public, acquired, and always-private firms. Inspection of columns (1) - (3) shows that both the IPO-firms and those that are cash-out through acquisition grow faster on average during their private phase than the always-private neveracquired firms. However, only the IPO firms exhibit a heightened responsiveness to growth opportunities.

Interestingly, there is also some evidence that private firms that eventually acquired by other private firms grow more slowly in periods of high credit spreads, particularly in their early years. Thus, firms that entrepreneurial firms that are taken over by private firms are encountering financial distress. This is consistent with the finding in Maksimovic, Phillips and Yang (2013) that the productivity gains from private acquisitions are lower than when the acquirer is public.

\section{IPO Firm Growth and Financially Dependent Industries}

One potential explanation for our finding that public firms are more responsive to demand shocks early in their public life is that the public status allows firm to raise capital more easily to respond to changing opportunities. To test this hypothesis, we separate industries into two groups based on their financial dependence. If the advantage of being public comes from better access to financing to fund high capital expenditures, then we would expect a bigger difference between public and private firms in industries with higher financial dependence.

We use Quarterly Financial Reports (QFR) data at Census in every $5^{\text {th }}$ year, which are the years available to us, to compute industry level financial dependence measures. ${ }^{20}$ The QFR has both income and balance sheet data for a stratified random sample of public and private firms. While only a sample of 200,000 firms exist in each year, thus preventing most firms in the LBD from being matched, there are sampling weights which allow us to create population estimates. We use this data to construct our indicator of industry financial dependence. We measure financial dependence using the rate of external financing calculated as the difference between capital

\footnotetext{
${ }^{20}$ For example, we use financial dependence identified in year 1982 for year 1982 to 1986, and financial dependence identified in 1987 for 1987-1991.
} 
expenditure and internal operating cash flow over total assets. We then separate all industry-years into two groups - those that are financially dependent $(F D)$ and those that are not financially dependent (Non_FD) based on whether the median rate of the industry is higher than the median of all industries in that year. Specifically, we estimate the following specification:

$$
\begin{gathered}
\text { Growth }=\beta_{0}+\beta_{1} P u b \times F D+\beta_{2} P u b \times N o n_{-} F D+\beta_{3}(D S \times P u b \times F D) \\
+\beta_{4}\left(D S \times P u b \times N o n_{-} F D\right)+\beta_{5}(C S \times P u b \times F D)+\beta_{6}\left(C S \times P u b \times N o n_{-} F D\right) \\
+\gamma \text { control variables }
\end{gathered}
$$

$\beta_{1}$ and $\beta_{2}$ capture the difference in growth rates between IPO firms in financially dependent or non-dependent industries and matched private firms, respectively. $\beta_{3}$ and $\beta_{4}$ capture the difference in responsiveness to demand shocks, and $\beta_{5}$ and $\beta_{6}$ capture the difference in responsiveness to financial shocks. As in our main regressions, we control for industry-year fixed effects. Table 11 presents our findings.

\section{[Insert Table 11 Here]}

Examination of the results presented in Table 11 reveals some interesting patterns. First, the differential growth between public and private firms post IPO is not higher in more financiallydependent industries. However, public firms in financially dependent industries are more responsive to industry growth opportunities than private firms. Again, the effect is most pronounced in years $(1,5)$, early in their public life. The estimated coefficient on demand shocks for financially dependent industries is higher in magnitude than that from our main regression in Table $5-0.694$ vs. 0.485 , and the estimated coefficient on demand shocks for financially nondependent industries is positive but not significantly from zero. This suggests that public firms' greater responsiveness to demand shock is mostly driven by firms in financially dependent industries. Interestingly, we do see that pre-IPO and in early years post-IPO, public firms in financially dependent industries grow faster in periods when financing is tight (i.e. higher credit differential). There is no corresponding differential in non-dependent industries. This result is consistent with the hypothesis that there is an advantage of being public when alternative sources of finance are more expensive. However, the effect disappears with firm age. 


\section{Firm Growth with Cross-Sectionally Matched Public and Private Firms}

Using a panel of public and private firms matched in 2001, AFL find that public firms respond significantly less to demand shocks than do private firm. Given that we find different results using birth-matched sample, we now explore whether their result may at least be partially attributable to matching in cross-section rather than at firm birth.

Similar to AFL, we match in the year 2001. For each public firm in 2001, we select up to five private firms closest in size and age in the same 3-digit SIC industry using the same criteria proposed by AFL requiring the ratio of their total assets is less than to 2 (i.e. max (TApublic, TAprivate) $/ \min \left(\mathrm{TA}_{\text {public }}, \mathrm{TA}_{\text {private }}\right)<2$ ). We discard the sample public firms if we cannot find any match. Once a match is formed, as in AFL, we follow the firms over time and keep the panel structure intact. We then use this matched sample to run our main specification to predict firm growth.

Table 12 Panel A presents summary statistics for our four subsamples - public and private firms, matched and unmatched. We are able to match about 5,800 public firms with 26,600 private counterparts. This sample and their matched private counterparts is much larger than the AFL sample as our data includes nearly all public firms in 2001. In our matched sample, public firms and private firms are similar in size, wage and productivity while public firms have lower growth rate in the previous three years and the trend continues after 2001. There is also an interesting pattern across different samples. Among all four groups, unmatched public firms are the biggest in size, most efficient, and have the highest growth rate. There are $550(8.7 \%)$ very large, very efficient public firms for which we cannot find matching private firms. In contrast, unmatched private firms are the smallest among all groups, least efficient, and have lower growth than matched private firms. The comparison suggests that when we match mature public firms in cross-section in the same year to private firms, we tend to match the less successful public firms with the more successful private firms.

[Insert Table 12 Here]

In Panel B, we examine firm growth in response to demand shocks using the sample matched in 2001. Column 1 includes all firm years while Column 2 - 5 split the sample by firm age with cutoffs set at 5, 10 and 20 years. We find some limited evidence that the matched public firms respond less to demand shocks relative to their cross-sectionally matched private counterparts. 
While negative, the effect is only marginally significant in our data. Comparing firms by age splits, we find that the negative coefficient is most prominent for firms in the age group of $(11,20)$. We attribute these findings to the fact that finding a size match to already public firms is difficult in many cases, resulting in adverse selection in the matched set of public firms. As shown in Panel A, it is more likely to find a match for public firms that have not done very in the well in the past and those firms grow at significantly lower rate than their matched private counterparts going forward. In addition, in our sample, in 2001, public firms have an average age of 17 years, and many have long passed their IPO year. Table 5 shows that there is little difference in growth between public and private firms five years after the IPO.

\section{Conclusions}

We examine the growth of IPO firms and private firms using a sample of 892,000 firms. We follow the growth of these firms throughout their life-cycle - from early years when all firms are private, to later years when some of the firms choose to go public and beyond. We compare the early growth patterns of public and private firms and their responses to industry demand shocks.

We find that the firm's characteristics at birth predict growth. Larger, initially faster growing and more productive firms remain on a faster growth trajectory in the subsequent ten to fifteen years. The same characteristics are predictors of future public status. Thus, public firms differ from most private firms not only in access to public markets, a treatment effect, but also in inherent quality, a selection effect. Our estimates show that over the first ten years, the selection effect is larger than the treatment effect.

We find that subsequently public firms differ from private firms matched on early birth characteristics in growth trajectories and sensitivity to growth opportunities. They grow faster prior to and approximately five years post the IPO and are more responsive to positive growth shocks for the first five years post-IPO. After that point, they grow at the same rate and have similar responsiveness to positive demand shocks as their initially matched private counterparts, albeit with the public firms being of a much larger size.

Taken together, our results show that public firms in their first 5 years post-IPO are more responsive to growth opportunities, especially in those industries that are dependent on external financing, and that their growth is efficient and does not lead to a riskier strategy

We use data on VC-sponsorship to further examine the selection effect. IPO firms that are sponsored by VC earlier in life respond even more to industry growth opportunities post IPO. We 
also show that our findings are not caused by high-quality matched private firms subsequently exiting through acquisition. The greater responsiveness of public firms to growth opportunities in early years after the IPO also holds when we match public and private firms one year prior to the IPO.

We reconcile our results with earlier research that finds that private firms are less responsive to growth opportunities. Using a cross-sectional match, we show that the differences in results are likely due to the fact that the earlier literature is not able to match very successful, large public firms in cross section. The cross-sectional matches used previously rely on matches of equallysized mature already public to private firms, whereby larger, more successful private firms are matched to relatively less successful public firms that are much smaller than the more successful public firms.

Overall, our results show that that there are economically important differences in the quality of firms that are evident early in the firms' lives. The quality differences predict future growth and public status. In addition, firms that become public grow faster are more responsive to demand shocks around the IPO date. Once the initial quality of the firms is controlled for, there is no evidence that public firms are less responsive to demand shocks than private firms. We show that public firms grow faster and respond more positively to positive demand shocks in the first five years post-IPO than birth-matched private firms. Thus, the evidence suggests that managerial myopia, which some believe characterizes public firms' responses to investment opportunities, is not likely to be a significant counterweight to the benefits of being public. 


\section{References}

Arikan, A. M., \& Stulz, R. M. (2011). Corporate acquisitions, diversification, and the firm's lifecycle (No. w17463). Working Paper, National Bureau of Economic Research.

Asker, J., J. Farre-Mensa, and A. Ljungqvist (2015). "Corporate Investment and Stock Market Listing: A Puzzle?” Review of Financial Studies 28, no. 2: 342-390

Ayyagari, M., A. Demirguc-Kunt, and V. Maksimovic (2017). "Does local financial development matter for firm lifecycle? Evidence from India," Review of Financial Studies, forthcoming.

Baker, M. and J. Wurgler (2000), "The Equity Share in New Issues and Aggregate Stock Returns," Journal of Finance 55, 2219-2257.

Bayar, O., and T. Chemmanur (2011). "IPOs versus acquisitions and the valuation premium puzzle: a theory of exit choice by entrepreneurs and venture capitalists." Journal of Financial and Quantitative Analysis 46: 1755-1793.

Benmelech, E., \& Frydman, C. (2014). "Military CEOs.” Journal of Financial Economics 117(1): 4359.

Bernstein, S. (2015). "Does going public affect innovation?" Journal of Finance 70, Issue 4, Pages $1365-1403$

Bernstein, S., X. Giroud, and R. Townsend (2016), "The impact of venture capital monitoring”, Journal of Finance 71 (4), 1591 - 1622

Bertrand, M., and Schoar, A. (2003). "Managing with style: The effect of managers on firm policies." Quarterly Journal of Economics Vol. 118, No. 4 (2003): 1169-1208.

Bhattacharya, S. and J. Ritter (1983). "Innovation and Communication: Signaling with Partial Disclosure", Review of Economic Studies 50, 331 - 346

Brav, O. (2009). "Access to capital, capital structure, and the funding of the firm." Journal of Finance 64(1), 263-308.

Celikyurt, U., Sevilir, M., \& Shivdasani, A. (2010). "Going public to acquire? The acquisition motive in IPOs.” Journal of Financial Economics 96(3), 345-363.

Chemmanur, T. J., and P. Fulghieri (1999). “A Theory of the Going-Public Decision.” Review of Financial Studies 12, 249-279.

Chemmanur, T., and J. He (2011). "IPO waves, product market competition, and the going public decision: Theory and evidence." Journal of Financial Economics 101: 382-412 
Chemmanur, T., S. He, and D. K. Nandy (2010). "The going-public decision and the product market." Review of Financial Studies 23: 1855 - 1908

Cronqvist, H., Makhija, A. K., \& Yonker, S. E. (2012). "Behavioral consistency in corporate finance: CEO personal and corporate leverage.” Journal of Financial Economics 103(1), 20-40.

Easton, P. D., \& Zmijewski, M. E. (1989). "Cross-sectional variation in the stock market response to accounting earnings announcements.” Journal of Accounting and Economics 11(2), 117-141.

Edmans, A. (2009). "Blockholder trading, market efficiency, and managerial myopia." Journal of Finance 64(6), 2481-2513.

Foster, L., Haltiwanger, J., \& Krizan, C. J. (2006). "Market selection, reallocation, and restructuring in the US retail trade sector in the 1990s." Review of Economics and Statistics 88(4), 748-758.

Gao, H., \& Li, K. (2015). "Large shareholders and CEO performance-based pay: New evidence from privately-held firms." Journal of Corporate Finance 35: 370-388.

Gao, X., J. Ritter, and Z. Zhu (2013), “Where Have All the IPOs Gone?,” Journal of Financial and Quantitative Analysis, Vol. 48, No. 6, 1663-1692.

Gilje, E., and Taillard, J. (2016). "Do private firms invest differently than public firms? Taking cues from the natural gas industry.” Journal of Finance 71 (4), 1733 - 1778

Hochberg, Y. (2012). "Venture capital and corporate governance in the newly public firm", Review of Finance 16 (2), 429 - 480.

Holmström, B. 1982. Managerial incentive problems: A dynamic perspective, in: Essays in Economics and Management in Honor of Lars Wahlbeck. Helsinki: Swedish School of Economics. Reprinted in Review of Economic Studies 66 (1999):169-82.

Hovakimian, A., \& Hutton, I. (2010). “Merger - Motivated IPOs.” Financial Management, 39(4), 1547-1573.

Hurst, E., and B. W. Pugsley (1982). "What Do Small Businesses Do?" Brookings Papers on Economic Activity Vol. 2, 73-118.

Jovanovic, B. (1982). "Selection and the Evolution of Industry." Econometrica: Journal of the Econometric Society 649-670.

Lemmon, M. L., M. R. Roberts, and J. Zender (2008). "Back to the Beginning: Persistence and the Cross-Section of Corporate Capital Structure.” Journal of Finance 63(4), 1575-1608.

Lyandres, E., M.T. Marchica, R. Michaely, and R. Mura (2013). The effects of owners' portfolio diversification on firm strategies: Theory and evidence from private and public firms, working paper Johnson School of Business, Cornell University. 
Lucas, R. E. (1978). “On the size distribution of business firms.” Bell Journal of Economics 9, 508523.

Lucas, D., and R. McDonald (1990), Equity issues and stock price dynamics, Journal of Finance 45, 1019-1043.

Maksimovic, V., and P. Pichler (2001). "Technological Innovation and Initial Public Offerings", Review of Financial Studies, 14, 459 - 494

Maksimovic, V., G. Phillips, and L. Yang (2013). "Private and Public Merger Waves.” Journal of Finance 2177-2217.

Miller, M., and K. Rock. 1985. Dividend policy under asymmetric information. Journal of Finance 40:1031-51.

Narayanan, M. 1985. Managerial incentives for short-term results. Journal of Finance 40:1469-84.

Pastor, L., and Veronesi, P. (2003). "Stock prices and IPO waves.” (No. w9858). Working Paper, National Bureau of Economic Research.

Phillips, G. and G. Sertsios, (2017), "Financing and New Product Decisions of Private and Publicly Traded Firms," Review of Financial Studies 30 (5): 1744-1789.

Puri, M., and R. Zarutskie (2012), "On the life cycle dynamics of venture-capital and non-venturecapital-financed firms, Journal of Finance 67 (6), 2247 - 2293.

Rajan, R. G., and L. Zingales (1998). "Financial dependence and growth.” American Economic Review 88, 559-587.

Rauch, J. E. (1991). "Modelling the informal sector informally." Journal of Development Economics $35,33-47$.

Ritter, J. (1987), “The Costs of Going Public”, Journal of Financial Economic Vol. 19, 269 - 281

Ritter, J. and I. Welch (2002), “A Review of IPO Activity, Pricing and Allocations," Journal of Finance Vol. 93, 1795-1828,

Stein, J. C. (1988). "Takeover threats and managerial myopia.” Journal of Political Economy 61-80

Stein, J. C. (1989), "Efficient capital markets, inefficient firms: A model of myopic corporate behavior." The Quarterly Journal of Economics 104.4 655-669.

Von Thadden, E.-L. 1995. Long-term contracts, short-term investment, and monitoring. Review of Economic Studies 62:557-75. 
Figure 1: Size Distribution of Public and Private Firms (Unmatched Sample)
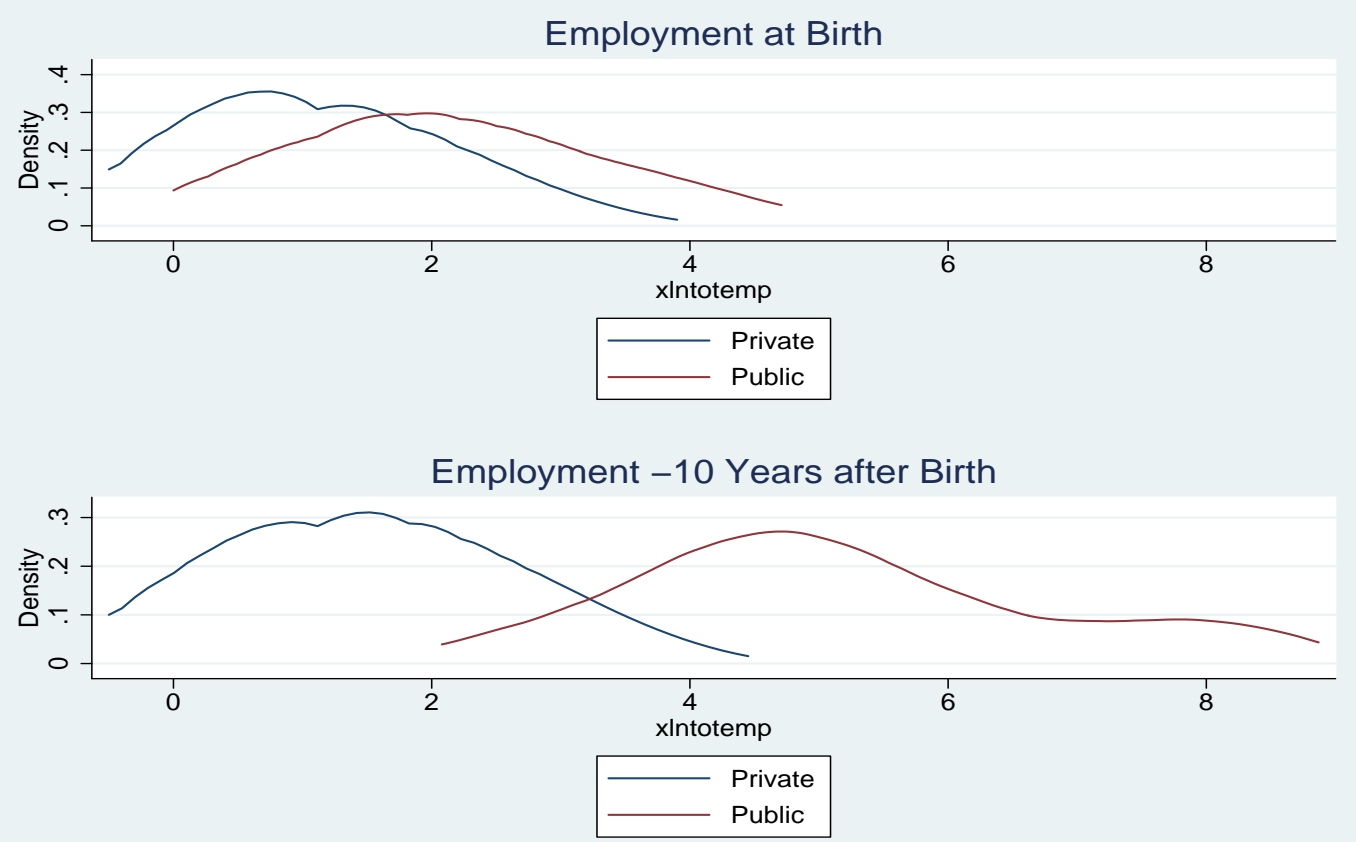

This figure presents the size distribution of public and private firms in our sample (unmatched) at birth (Panel A) and 10 years after birth (Panel B). 
Figure 2: Initial Conditions and Firm Growth
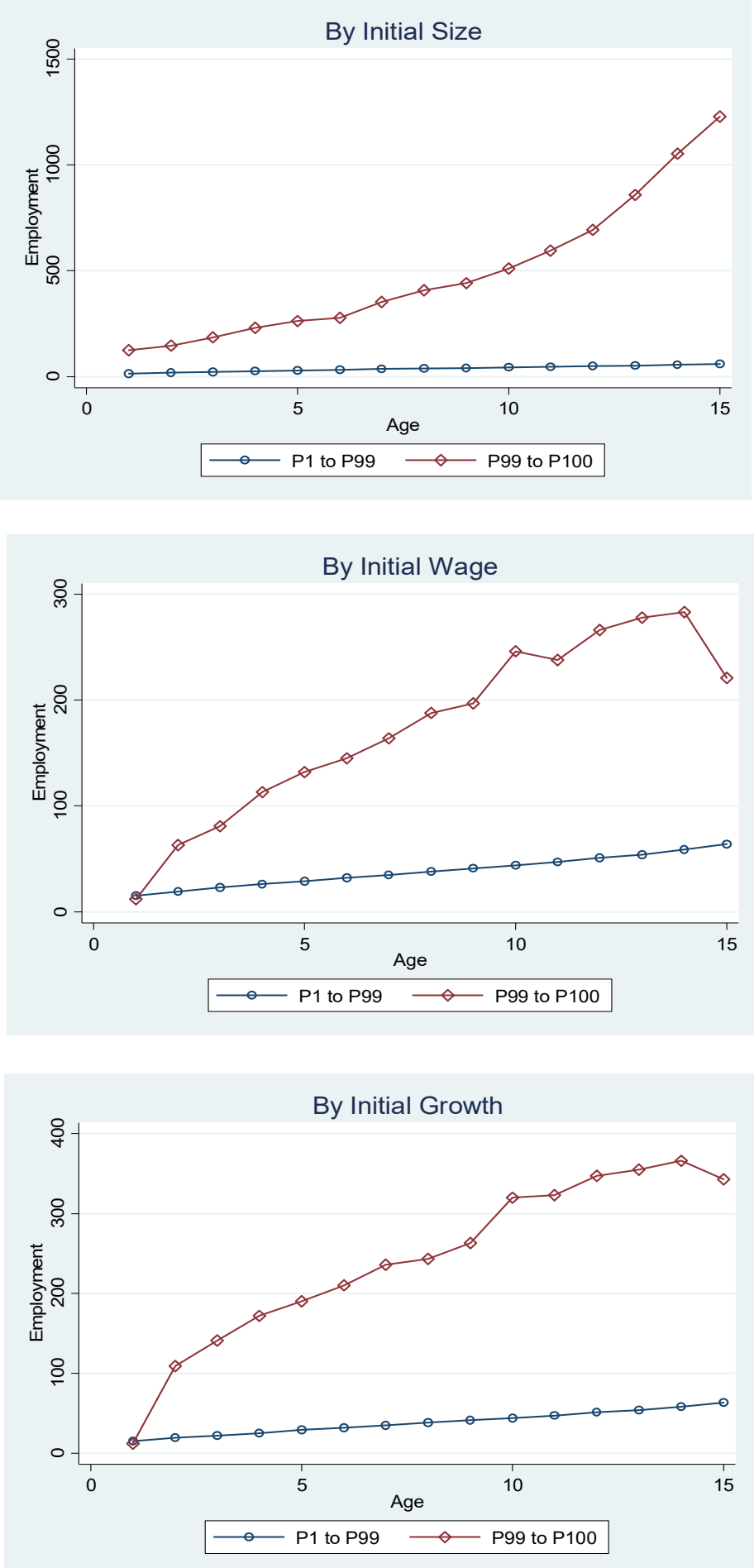

The figures compare firm size (number of employees) over time for firms in the 1st-99th percentile and firms above 99th percentile based on initial conditions - size, wage, and initial growth rate, respectively. 


\section{Figure 3: Top 1\% Firms: Public vs. Private}

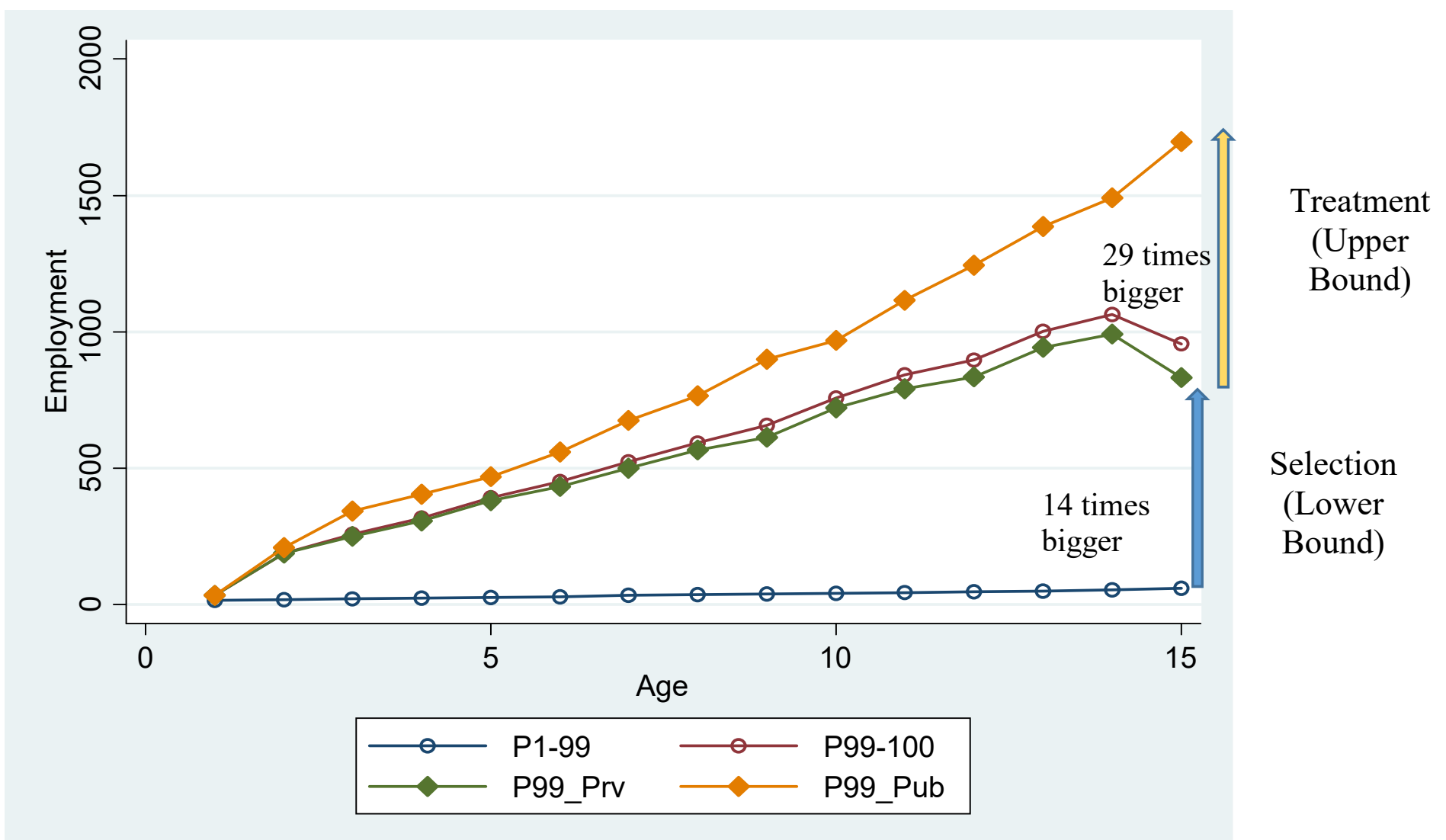

This figure shows the average number of employees for firms at the top $1 \%$ of the predicted public quality (P99-100) and those in the rest of the population (P1-99) by their actual public status later in life. P99_Prv and P99_Pub refer to the top $1 \%$ firms that stay private and become public later, respectively. Thus, the difference between P99_Prv and P1-99 captures the lower bound of selection effect while the difference between P99_Pub and P99_Prv captures the upper bound of treatment effect. 


\section{Figure 4: Matched Sample}
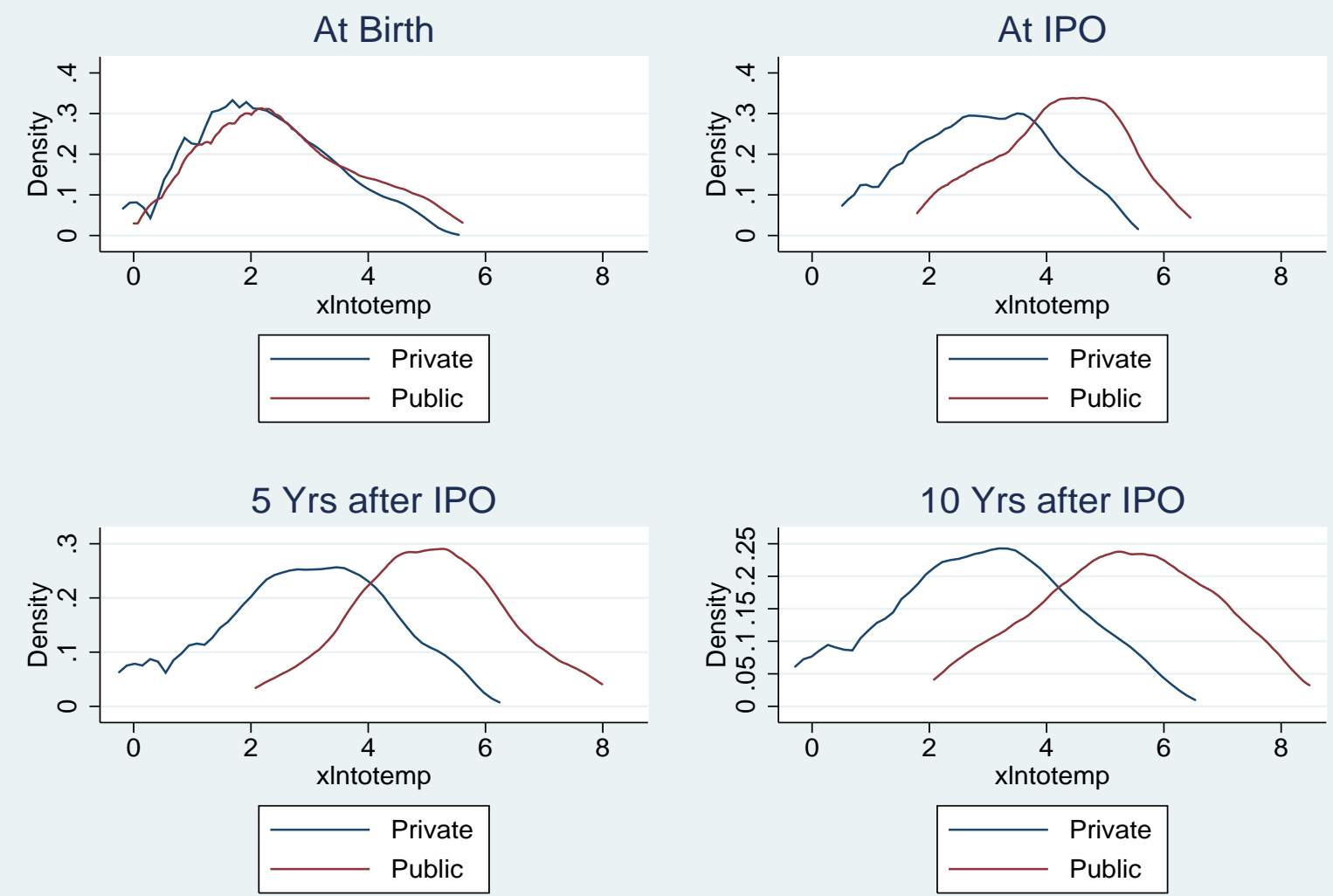

This figure represents the distribution density of the log of number of employees for public firms and their matched private counter parts over time - at birth, at IPO, 5 years after IPO, and 10 years after IPO. For each public firm, we choose up to 10 matched private firms from the same industry and same birth year based on the predicted probability of being public (based on Table 2 Column 2). 
Figure 5: Growth around IPO

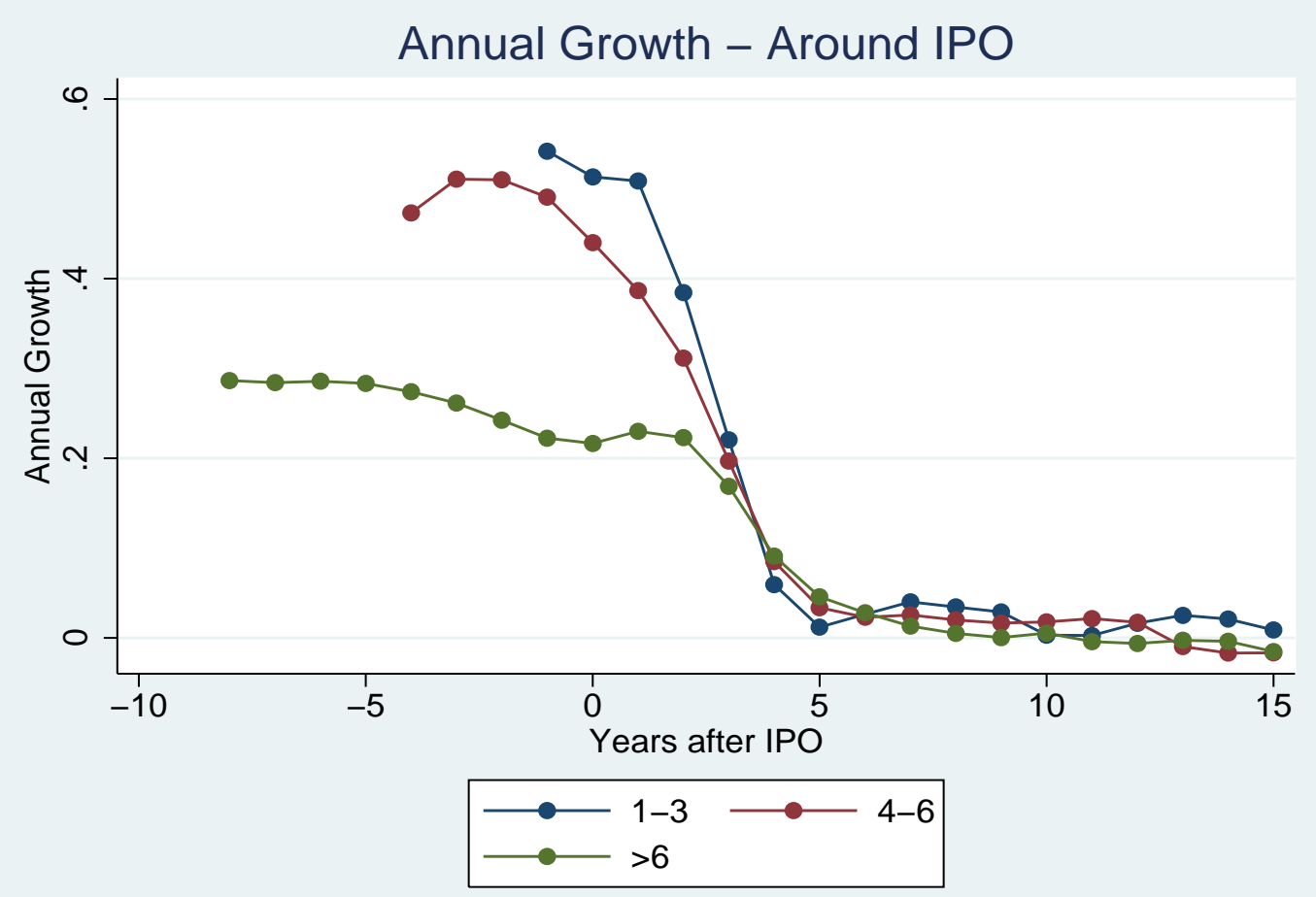

This figure plots the annual growth rate for public firms around the IPO. We separate the IPO firms in groups based the age of IPO (less than 3 years, year 4 to 6 , or after 6 years) 


\section{Table 1: Persistence in Initial Conditions}

This table presents estimateed coefficients to predit a firm's size later in life based on macro, industry, and firm conditions at birth. The dependent variables are employment size 5, 10, or 15 years after birth, respectively. We include year and industry fixed effects in all specifications. Industries are defined using 3-digit SIC level. Initial employment measures number of employees in the first year reported by firm. Initial wage is calculated as the average wage paid by firm in the first year. Initial growth measures the growth of employment in the first year. Robust standard errors allow for clustering at the industry-year level and are reported in parentheses. * $* *$, and $* * *$ represent significance at the $10 \%, 5 \%$, and $1 \%$ level, respectively.

\begin{tabular}{l|c|c|c}
\hline $\begin{array}{l}\text { Dependent Var: } \\
\text { Employment }\end{array}$ & $\begin{array}{c}\text { Panel A: Year 5 } \\
(1)\end{array}$ & $\begin{array}{c}\text { Panel B: Year 10 } \\
(2)\end{array}$ & $(3)$ \\
\hline Initial Employment & $1.631 * * *$ & $2.639 * * *$ & $3.282 * * *$ \\
& $(0.010)$ & $(0.038)$ & $(0.121)$ \\
Initial Wage & $0.637 * * *$ & $1.401 * * *$ & $2.042 * * *$ \\
& $(0.024)$ & $(0.094)$ & $(0.356)$ \\
Initial Growth (x 100) & $0.350 * * *$ & $0.514 * * *$ & $0.771 * * *$ \\
& $(0.006)$ & $(0.025)$ & $(0.084)$ \\
\hline Number of Observation & 463,000 & 268,000 & 162,000 \\
R-square & $8.16 \%$ & $3.90 \%$ & $1.07 \%$ \\
Year FE & Yes & Yes & Yes \\
Industry FE & Yes & Yes & Yes \\
\hline
\end{tabular}




\section{Table 2: Predicting Public Status}

This table presents the estimated coeffcients to predict a firm's public status. The dependent variable equals to 1 if a firm becomes publicly traded later in life and 0 otherwise. $\log$ (Initial_Emp) is the logarithm of the number of employees at birth. $\log$ (Initial Wage) is the logarithm of average wage paid by the firm at birth. Initial_Growth is the firm's growth rate (in employment) in the first year. Pct_Small_Firms is the percentage of firms that have fewer than 50 employees in the industry. Ind_Growth is the average growth (in employment) in the industry, and Pct_M\&A is the percentage of employment involved in mergers and acquisitions (from target firms) in the industry. Industries are defined using 3-digit SIC level. We control for industry (3-digit SIC) fixed effects and year fixed effects in all regressions. Robust standard errors allow for clustering at the industry-year level and are reported in parentheses. $*, * *$, and $* * *$ represent significance at the $10 \%, 5 \%$, and $1 \%$ level, respectively.

\begin{tabular}{|c|c|c|}
\hline \multirow{3}{*}{$\frac{\text { Dep Var: } 1 \text { (Public) }}{\text { Log(Initial_Emp) }}$} & $(1)$ & $(2)$ \\
\hline & -0.003 & 0.005 \\
\hline & $(0.058)$ & $(0.058)$ \\
\hline $\log (\text { Initial_Emp })^{\wedge} 2$ & $0.037 * * *$ & $0.036 * * *$ \\
\hline & $(0.010)$ & $(0.010)$ \\
\hline Log(Initial Wage) & $\begin{array}{l}-0.570 * * * \\
(0.066)\end{array}$ & $\begin{array}{l}-0.578 * * * \\
(0.066)\end{array}$ \\
\hline $\log (\text { Initial Wage })^{\wedge} 2$ & $\begin{array}{l}0.177^{* * *} \\
(0.018)\end{array}$ & $\begin{array}{l}0.178 * * * \\
(0.018)\end{array}$ \\
\hline Initial_Growth & $\begin{array}{l}0.354 * * * \\
(0.032)\end{array}$ & $\begin{array}{l}0.351 * * * \\
(0.032)\end{array}$ \\
\hline Initial_Growth ${ }^{\wedge} 2$ & $\begin{array}{l}0.211 * * * \\
(0.023)\end{array}$ & $\begin{array}{l}0.209 \text { *** } \\
(0.023)\end{array}$ \\
\hline Ind_Growth & & $\begin{array}{l}0.772 \text { *** } \\
(0.263)\end{array}$ \\
\hline Pct_M\&A & & $\begin{array}{l}8.659 * * * \\
(2.123)\end{array}$ \\
\hline Pct_Small_Firms & & $\begin{array}{l}-0.673 * * * \\
(0.133)\end{array}$ \\
\hline R-Square & 0.016 & 0.016 \\
\hline Number of Observations & 892,000 & 892,000 \\
\hline Industry FE & Yes & Yes \\
\hline Year FE & Yes & Yes \\
\hline
\end{tabular}




\section{Table 3: Public Index and Firm Growth}

This table reports the estimated coefficients of regressing firm growth on an indicator of high public index. We define high public quality index (HPI) equal to 1 if the estimated public index based on initial conditions (estimated in Table 2 Column 2) is above the 99th percentile of all firms at birth and zero otherwise. The dependent variable is the annual employment growth. DS is an industry level (at 3-digit SIC) measure for demand shock constructed based on changes of shipment from vertical industries. CS measures the credit spread for the year. We control for industry and year fixed effects in all regressions. Robust standard errors allow for clustering at the industry-year level and are reported in parentheses. ${ }^{*},{ }^{* *}$, and ${ }^{* * *}$ represent significance at the $10 \%, 5 \%$, and $1 \%$ level, respectively.

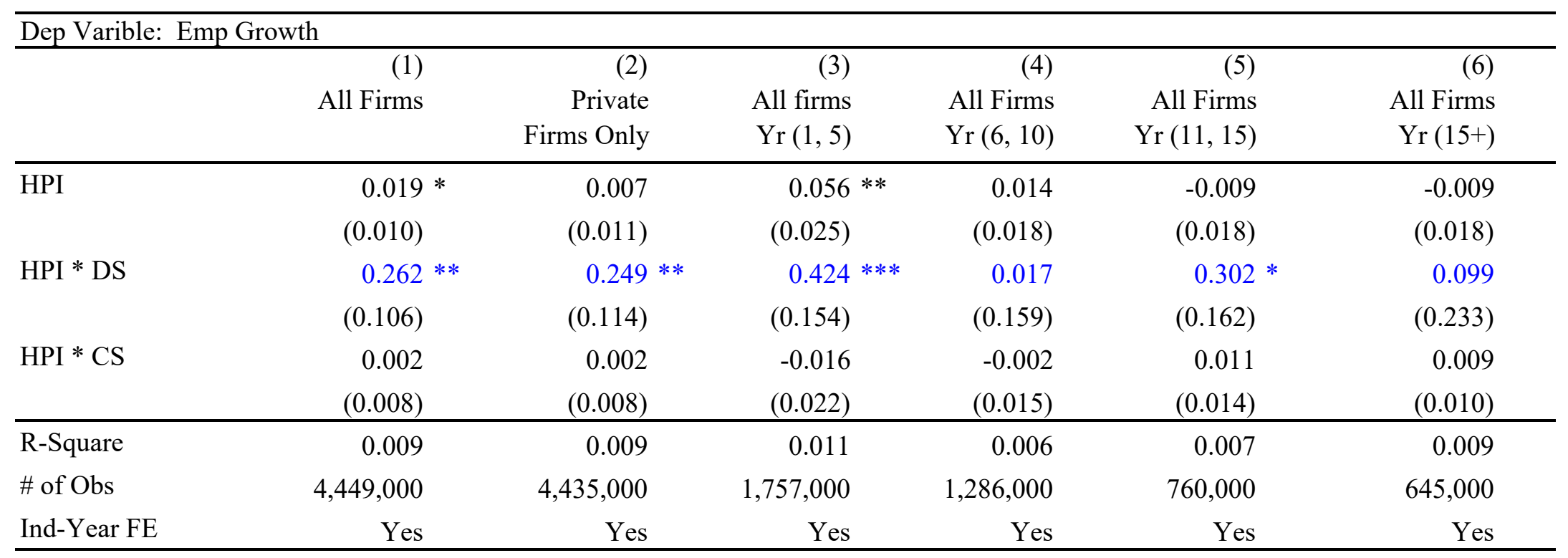




\section{Table 4: Summary Statistics for Matched Sample}

This table presents the summary statistics for our matched sample. For each public firm, we choose up to 5 matched private firms from the same industry and the same birth year based on the predicted probability of being public (using Table 2 column 2). Colunm (3) and (5) present the t-statistics comparing the group mean between (1) and (2), and between (1) and (4), respectively. Standard errors are shown in parentheses.

\begin{tabular}{|c|c|c|c|c|c|}
\hline & $\begin{array}{c}(1) \\
\text { Public Firms }\end{array}$ & $\begin{array}{c}(2) \\
\text { Private Firms } \\
\text { (Matched) }\end{array}$ & $\begin{array}{c}\text { (3) } \\
\text { t-stat } \\
(1) \mathrm{vs}(2)\end{array}$ & $\begin{array}{c}(4) \\
\text { Private Firms } \\
\text { (Unmatched) }\end{array}$ & $\begin{array}{c}(5) \\
\text { t-stat } \\
(1) \text { vs (4) }\end{array}$ \\
\hline Phat & $\begin{array}{c}0.83 \% \\
(0.011 \%)\end{array}$ & $\begin{array}{c}0.81 \% \\
(0.005 \%)\end{array}$ & 1.56 & $\begin{array}{c}0.28 \% \\
(0.005 \%)\end{array}$ & 49.39 \\
\hline Initial Employment & $\begin{array}{l}27.01 \\
(1.07)\end{array}$ & $\begin{array}{l}26.37 \\
(0.49)\end{array}$ & 0.54 & $\begin{array}{l}18.42 \\
(0.03)\end{array}$ & 8.02 \\
\hline Initial Wage & $\begin{array}{l}61.79 \\
(1.33)\end{array}$ & $\begin{array}{l}65.45 \\
(0.65)\end{array}$ & -2.46 & $\begin{array}{l}16.41 \\
(0.02)\end{array}$ & 33.88 \\
\hline Growth Rate & $\begin{array}{c}0.767 \\
(0.018)\end{array}$ & $\begin{array}{c}0.794 \\
(0.009)\end{array}$ & -1.32 & $\begin{array}{c}-0.058 \\
(0.0006)\end{array}$ & 44.80 \\
\hline Number of Obs. & 1,600 & 8,000 & & 886,000 & \\
\hline
\end{tabular}


Table 5: Response to Demand Shocks by Public Status

This table presents the estimated coeffcients of regressing firm growth on public status and demand shocks for the matched sample of public and private firms. For each public firm, we select up to 5 matched private firms based on initial conditions and survivial up to the IPO year. The dependent variable is the growth of employment for a firm in a specific year. Column 1 includes all firm years (from up to five years before the IPO to up to 10 years after the IPO); column 2 includes firm years from up to five years prior to IPO; column 3 includes firm years that are up to five years following the IPO; and column 4 includes firm years that are between 6 and 10 years following the IPO. We control for firm-cohortperiod fixed effects in column (5) and (6). Pub is an indicator that equals to 1 if a firm becomes publicly traded at some point in its life and zero otherwise. PostIPO_1 to5 is an indicator variable that equals to one for firm-years that are within the first five years following the IPO and zero otherwise. PostIPO_5+ is an indicator variable that equals to one for firm-years that are five years after the IPO date and zero otherwise. DS measures the industry-level (3-digit SIC) demand shock constructed based on changes of shipment from vertical industries. CS measures the annual credit spread using the difference in rates between the A3 and Baa rated-bonds. $\log (\mathrm{Emp})$ is the logarithm of firm employment. $\log ($ Wage $)$ is the logarithm of firm's average wage. Age measures firm's age following birth. All dependent variables are lagged. Industryies are defined using the 3-digit SIC codes. Robust standard errors are clustered at the industry-year level and reported in parentheses. $*, * *$, and *** represent significance at the $10 \%, 5 \%$, and $1 \%$ level, respectively.

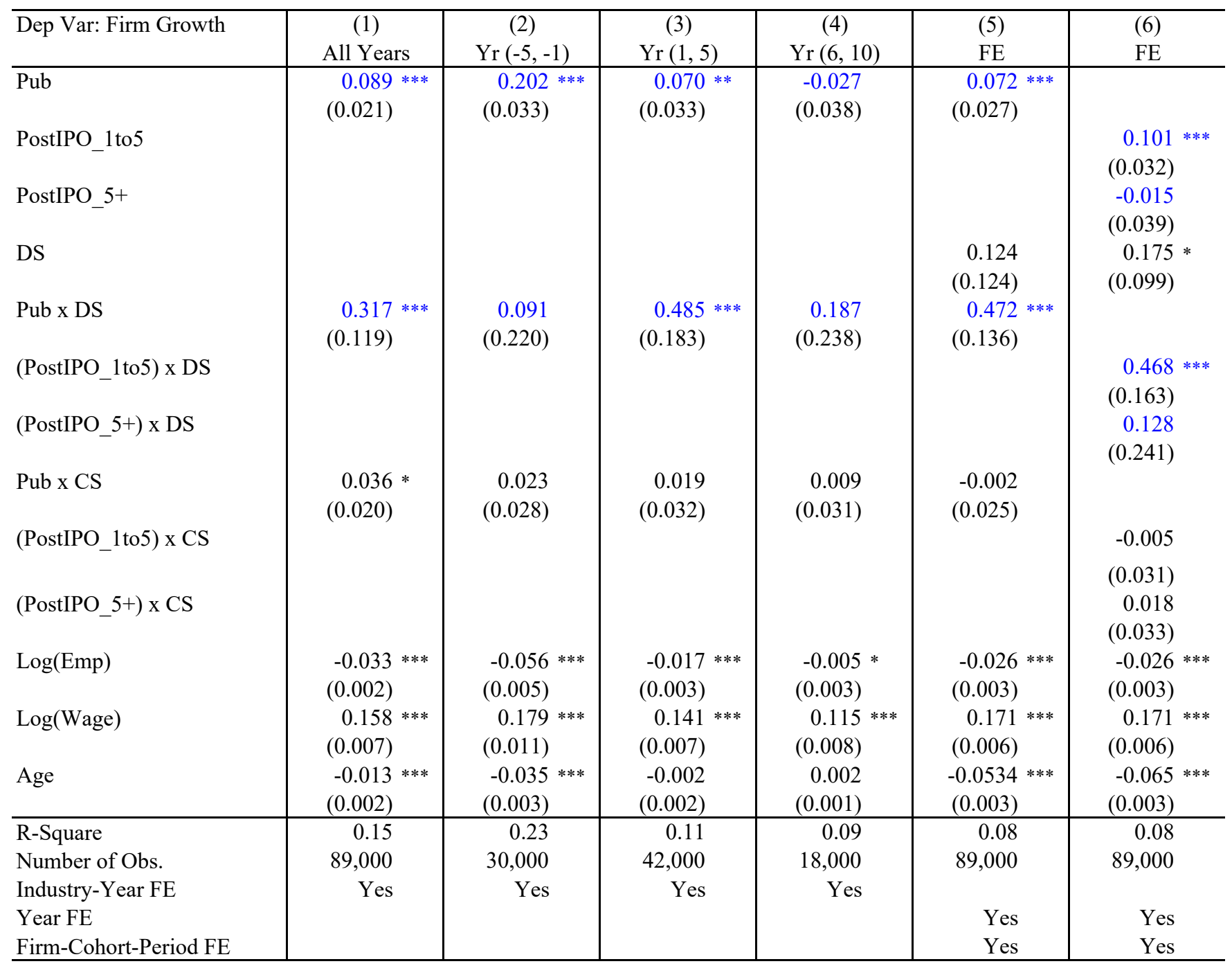




\section{Table 6: Efficiency by Public Status}

This table presents the estimated coeffcients of regressing efficiency (measured as sales over employment) on public status and demand shock for the matched sample of public and private firms. For each public firm, we select up to 5 matched private firms based on initial conditions and survivial up to the IPO year. The dependent variable is the growth of employment for a firm in a specific year. Column 1 includes all firm years (from up to five years before the IPO to up to 10 years after the IPO); column 2 includes firm years from up to five years prior to IPO; column 3 includes firm years that are up to five years following the IPO; and column 4 includes firm years that are between 6 and 10 years following the IPO. We control for firm-cohort-period fixed effects in column (5) and (6). Pub is an indicator that equals to 1 if a firm becomes publicly traded at some point in its life and zero otherwise. PostIPO_1 to5 is an indicator variable that equals to one for firm-years that are within the first five years following the IPO and zero otherwise. PostIPO_5+ is an indicator variable that equals to one for firm-years that are five years after the IPO date and zero otherwise. DS measures the industry-level (3-digit SIC) demand shock constructed based on changes of shipment from vertical industries. CS measures the annual credit spread using the difference in rates between the A3 and Baa rated-bonds. $\log (\mathrm{Emp})$ is the $\operatorname{logarithm}$ of firm employment. Log(Wage) is the logarithm of firm's average wage. Age measures firm's age following birth. All dependent variables are lagged. Industryies are defined using the 3-digit SIC codes. Robust standard errors are clustered at the industry-year level and reported in parentheses. $* * *$, and $* * *$ represent significance at the $10 \%, 5 \%$, and $1 \%$ level, respectively.

\begin{tabular}{|c|c|c|c|c|c|c|}
\hline Dep Var: Sales/Emp & $\begin{array}{c}(1) \\
\text { All Years }\end{array}$ & $\begin{array}{c}(2) \\
\operatorname{Yr}(-5,-1) \\
\end{array}$ & $\begin{array}{c}(3) \\
\operatorname{Yr}(1,5) \\
\end{array}$ & $\begin{array}{c}(4) \\
\operatorname{Yr}(6,10) \\
\end{array}$ & $\begin{array}{l}(5) \\
\mathrm{FE}\end{array}$ & $\begin{array}{l}(6) \\
\mathrm{FE}\end{array}$ \\
\hline Pub & $\begin{array}{r}0.048 \\
(0.126)\end{array}$ & $\begin{array}{l}0.239 * \\
(0.137)\end{array}$ & $\begin{array}{r}0.160 \\
(0.158)\end{array}$ & $\begin{array}{l}-0.305 \\
(0.261)\end{array}$ & $\begin{array}{r}0.050 \\
(0.153)\end{array}$ & \\
\hline PostIPO_1to5 & & & & & & $\begin{array}{r}0.188 \\
(0.159) \\
-0.092\end{array}$ \\
\hline PostlPO_5+ & & & & & & $\begin{array}{l}-0.092 \\
(0.316)\end{array}$ \\
\hline DS & & & & & $\begin{array}{r}0.215 \\
(0.187)\end{array}$ & $\begin{array}{r}0.042 \\
(0.160)\end{array}$ \\
\hline Pub x DS & $\begin{array}{l}1.550 \text { *** } \\
(0.476)\end{array}$ & $\begin{array}{l}1.1666^{* *} \\
(0.543)\end{array}$ & $\begin{array}{l}1.972 * * * \\
(0.551)\end{array}$ & $\begin{array}{r}1.896 \\
(1.505)\end{array}$ & $\begin{array}{l}1.039 * \\
(0.593)\end{array}$ & \\
\hline $\begin{array}{l}\text { (PostIPO_1to5) x DS } \\
(\text { PostIPO_5+) x DS }\end{array}$ & & & & & & $\begin{array}{c}1.106 * * \\
(0.547) \\
1.583 \\
(1.674)\end{array}$ \\
\hline $\begin{array}{l}\text { Pub x CS } \\
\text { (PostIPO_1to5) x CS }\end{array}$ & $\begin{array}{r}-0.107 \\
(0.110)\end{array}$ & $\begin{array}{l}-0.266^{* *} \\
(0.105)\end{array}$ & $\begin{array}{l}-0.292 * \\
(0.154)\end{array}$ & $\begin{array}{r}0.495 \\
(0.210)\end{array}$ & $\begin{array}{r}0.025 \\
(0.142)\end{array}$ & -0.219 \\
\hline (PostIPO_5+) x CS & & & & & & $\begin{array}{c}(0.150) \\
0.486 * \\
(0.262)\end{array}$ \\
\hline $\log (E m p)$ & $\begin{array}{l}-0.040 * * \\
(0.018)\end{array}$ & $\begin{array}{l}-0.081 * * * \\
(0.016)\end{array}$ & $\begin{array}{l}-0.064 * * * \\
(0.021)\end{array}$ & $\begin{array}{l}-0.016 * * \\
(0.026)\end{array}$ & $\begin{array}{l}-0.086 \text { *** } \\
(0.019)\end{array}$ & $\begin{array}{l}-0.087 \text { *** } \\
(0.019)\end{array}$ \\
\hline Log(Wage) & $\begin{array}{l}0.653 \text { *** } \\
(0.029)\end{array}$ & $\begin{array}{l}0.512 * * * \\
(0.032)\end{array}$ & $\begin{array}{l}0.658 * * * \\
(0.035)\end{array}$ & $\begin{array}{l}0.853 * * * \\
(0.064)\end{array}$ & $\begin{array}{l}0.618^{* * *} \\
(0.031)\end{array}$ & $\begin{array}{l}0.617^{* * *} \\
(0.031)\end{array}$ \\
\hline Age & $\begin{array}{l}0.044 * * * \\
(0.003)\end{array}$ & $\begin{array}{l}0.049^{* * * *} \\
(0.006) \\
\end{array}$ & $\begin{array}{l}0.043 * * * \\
(0.005) \\
\end{array}$ & $\begin{array}{l}0.017^{* * *} \\
(0.006) \\
\end{array}$ & $\begin{array}{l}0.0459 * * * \\
(0.005)\end{array}$ & $\begin{array}{l}0.039^{* * *} \\
(0.005)^{2}\end{array}$ \\
\hline R-Square & 0.28 & 0.32 & 0.28 & 0.36 & 0.12 & 0.12 \\
\hline Number of Obs. & 45,000 & 13,000 & 23,000 & 10,000 & 45,000 & 45,000 \\
\hline Industry-Year FE & Yes & Yes & Yes & Yes & & \\
\hline Year FE & & & & & Yes & Yes \\
\hline Firm-Cohort-Period FE & & & & & Yes & Yes \\
\hline
\end{tabular}




\section{Table 7: Survival by Public Status - Cox Proportional Hazard Model}

This table reports the analysis of survivial rate based on public status. Panel A describes the coefficents from a Cox Proportional Hazard Model estimated from the matched sample of public and private firms. For each public firm, we select up to 5 matched private firms based on initial conditionsand survivial up to the IPO year. We include all firm years up to fifteen years following the IPO. Failure is defined as the event that a firm does not survive in the next year. Pub is an indicator that equals to 1 if a firm becomes publicly traded at some point of its life. IPO_wave is an indicator variable that equals one if the firm went public during IPO waves and zero otherwise. IPO waves are defined as years in which the number of IPOs is two standard deviations above the average in the sample period using Ritter's data. We control for industry-year fixed effects in all regressions. Industryies are defined using the 3 -digit SIC codes. *, **, and *** represent significance at the $10 \%$, $5 \%$, and $1 \%$ level, respectively. Panel B predicts ithe survivial rate by public status and IPO age using estimates from column (2).

Panel A: Cox Proportional Hazard Model

\begin{tabular}{l|c|c}
\hline & $(1)$ & $(2)$ \\
\hline Pub & $-0.194 * * *$ & $-0.230^{* * *}$ \\
IPO_Wave & $(0.044)$ & $(0.051)$ \\
& & 0.061 \\
Pub* IPO_Wave & & $(0.045)$ \\
& & 0.117 \\
\hline Number of Obs & & $(0.089)$ \\
Log Likelihood & 76000 & 76000 \\
\hline
\end{tabular}

Panel B: Survivial Rate following IPO by Public Status and IPO Age

\# of Yrs After IPO Private Firms IPO Firms

\begin{tabular}{rrr}
\hline 0 & $100 \%$ & $100 \%$ \\
1 & $100 \%$ & $100 \%$ \\
2 & $93 \%$ & $98 \%$ \\
3 & $86 \%$ & $94 \%$ \\
4 & $80 \%$ & $89 \%$ \\
5 & $74 \%$ & $83 \%$ \\
6 & $69 \%$ & $78 \%$ \\
7 & $65 \%$ & $73 \%$ \\
8 & $61 \%$ & $67 \%$ \\
9 & $57 \%$ & $62 \%$ \\
10 & $53 \%$ & $58 \%$ \\
11 & $49 \%$ & $53 \%$ \\
12 & $47 \%$ & $50 \%$ \\
13 & $45 \%$ & $48 \%$ \\
14 & $43 \%$ & $44 \%$ \\
15 & $40 \%$ & $41 \%$ \\
\hline
\end{tabular}




\section{Table 8: Response to Demand Shocks by Public Status and VC Sponsorship}

This table presents the estimated coeffcients of regressing firm growth on public status, demand shocks, and financial dependence for the matched sample of public and private firms. For each public firm, we select up to 5 matched private firms based on initial conditions and survivial up to the IPO year. The dependent variable is the annual growth rate of employment in a specific year. Pub is an indicator that equals to 1 if a firm becomes publicly traded at some point in its life and zero otherwise. Column 1 includes all firm years (from up to five years before the IPO to up to 10 years after the IPO); column 2 includes firm years from up to five years prior to IPO; column 3 includes firm years that are up to five years following the IPO; and column 4 includes firm years that are between 6 and 10 years following the IPO. PostIPO is an indicator variable that equals to 1 for public years and zero for private firms or public firms prior to the IPO. We include firm-cohort period fixed effects in column 5. Non-VC (VC) is an indicator variable that equals to 1 if the public firm does not (does) have VC sponsorship. DS measures the industry-leve (3-digit SIC) demand shock constructed based on changes of shipment from vertical industries. CS measures the credit spread using the difference between the A3 and Baa rated-bonds for the year. $\log (\mathrm{Emp})$ is the logarithm of firm employment. Log(Wage) is the logarithm of firm's average wage. Age measures firm's age following birth. All dependent variables are lagged. We control for industry-year fix $\epsilon$ effects in all regressions. Industryies are defined using the 3-digit SIC codes. Robust standard errors are clustered at the industry-year level and reported in parentheses. $*, *$, and $* * *$ represent significance at the $10 \%, 5 \%$, and $1 \%$ level, respectively.

\begin{tabular}{|c|c|c|c|c|c|}
\hline Dep Var: Firm Growth & $\begin{array}{c}(1) \\
\text { All Years }\end{array}$ & $\begin{array}{c}(2) \\
\operatorname{Yr}(-5,-1)\end{array}$ & $\begin{array}{c}(3) \\
\operatorname{Yr}(1,5)\end{array}$ & $\begin{array}{c}(4) \\
\operatorname{Yr}(6,10)\end{array}$ & $\begin{array}{l}(5) \\
\mathrm{FE}\end{array}$ \\
\hline Pub x Non-VC & $\begin{array}{l}0.054^{* *} \\
(0.027)\end{array}$ & $\begin{array}{l}0.193^{* * *} \\
(0.041)\end{array}$ & $\begin{array}{r}0.044 \\
(0.042)\end{array}$ & $\begin{array}{l}-0.030 \\
(0.055)\end{array}$ & \\
\hline Pub x VC & $\begin{array}{l}0.1244^{* * *} \\
(0.028)\end{array}$ & $\begin{array}{l}0.192^{* * *} \\
(0.045)\end{array}$ & $\begin{array}{l}0.102 \text { ** } \\
(0.045)\end{array}$ & $\begin{array}{r}-0.004 \\
(0.050)\end{array}$ & \\
\hline $\begin{array}{l}\text { PostIPO x Non-VC } \\
\text { PostIPO x VC }\end{array}$ & & & & & $\begin{array}{c}0.060 * \\
(0.036) \\
0.083 * * \\
(0.033)\end{array}$ \\
\hline Pub x Non-VC x DS & $\begin{array}{c}0.270 \\
(0.146)\end{array}$ & $\begin{array}{r}0.231 \\
(0.229)\end{array}$ & $\begin{array}{r}0.224 \\
(0.207)\end{array}$ & $\begin{array}{c}0.605 \\
(0.349)\end{array}$ & \\
\hline Pub $x$ VC x DS & $\begin{array}{c}0.299 * \\
(0.164)\end{array}$ & $\begin{array}{r}-0.049 \\
(0.280)\end{array}$ & $\begin{array}{l}0.6644^{* * *} \\
(0.252)\end{array}$ & $\begin{array}{r}-0.169 \\
(0.322)\end{array}$ & \\
\hline $\begin{array}{l}\text { PostIPO x Non-VC x DS } \\
\text { PostIPO x VC x DS }\end{array}$ & & & & & $\begin{array}{l}0.133 \\
(0.205) \\
0.477 * * * \\
(0.173)\end{array}$ \\
\hline Pub x Non-VC x CS & $\begin{array}{l}0.055 * * \\
(0.025)\end{array}$ & $\begin{array}{r}0.001 \\
(0.036)\end{array}$ & $\begin{array}{r}0.053 \\
(0.039)\end{array}$ & $\begin{array}{r}-0.010 \\
(0.050)\end{array}$ & \\
\hline Pub x VC x CS & $\begin{array}{r}0.020 \\
(0.027)\end{array}$ & $\begin{array}{r}0.060 \\
(0.039)\end{array}$ & $\begin{array}{l}-0.020 \\
(0.047)\end{array}$ & $\begin{array}{r}0.008 \\
(0.038)\end{array}$ & \\
\hline PostIPO x Non-VC x CS & & & & & $\begin{array}{r}0.009 \\
(0.033)\end{array}$ \\
\hline PostIPO x VC x CS & & & & & $\begin{array}{r}-0.022 \\
(0.031)\end{array}$ \\
\hline $\log (E m p)$ & $\begin{array}{l}-0.033^{* * * *} \\
(0.002)\end{array}$ & $\begin{array}{l}-0.056^{* * *} \\
(0.005)\end{array}$ & $\begin{array}{l}-0.0177^{* * * *} \\
(0.003)\end{array}$ & $\begin{array}{l}-0.005 * \\
(0.003)\end{array}$ & $\begin{array}{l}-0.026 * * * \\
(0.003)\end{array}$ \\
\hline Log(Wage) & $\begin{array}{l}0.157^{* * *} \\
(0.007)\end{array}$ & $\begin{array}{l}0.178 \text { *** } \\
(0.011)\end{array}$ & $\begin{array}{l}0.141^{* * *} \\
(0.007)\end{array}$ & $\begin{array}{l}0.115^{* * *} \\
(0.008)\end{array}$ & $\begin{array}{l}0.166^{* * *} \\
(0.006)\end{array}$ \\
\hline Age & $\begin{array}{l}-0.013 \text { *** } \\
(0.002)\end{array}$ & $\begin{array}{l}-0.035 * * * \\
(0.003)\end{array}$ & $\begin{array}{r}-0.002 \\
(0.002) \\
\end{array}$ & $\begin{array}{r}0.002 \\
(0.001) \\
\end{array}$ & $\begin{array}{l}-0.017 \text { *** } \\
(0.001)\end{array}$ \\
\hline $\begin{array}{l}\text { R-Square } \\
\text { Number of Obs. }\end{array}$ & $\begin{array}{r}0.15 \\
89,000\end{array}$ & $\begin{array}{r}0.23 \\
30,000\end{array}$ & $\begin{array}{r}0.12 \\
42,000\end{array}$ & $\begin{array}{r}0.09 \\
18,000\end{array}$ & $\begin{array}{r}0.10 \\
89,000\end{array}$ \\
\hline $\begin{array}{l}\text { Industry-Year FE } \\
\text { Year FE } \\
\text { Firm-Cohort Period FE }\end{array}$ & Yes & Yes & Yes & Yes & $\begin{array}{l}\text { Yes } \\
\text { Yes }\end{array}$ \\
\hline
\end{tabular}


Table 9: Firm Internal Growth Response to Demand Shocks by Public Status

This table presents the estimated coeffcients of regressing firm's internal growth on public status and demand shocks for the matched sample of public and private firms. For each public firm, we select up to 5 matched private firms based on initial conditions and survivial up to the IPO year. The dependent variable is the growth of employment for a firm in a specific year. Column 1 includes all firm years (from up to five years before the IPO $t$, up to 10 years after the IPO); column 2 includes firm years from up to five years prior to IPO; column 3 includes firm years that are up to five years following the IPO; and column 4 includes firm years that are between 6 and 10 years following the IPO. We control for firm-cohort-period fixed effects in column (5) and (6). Pub is an indicator that equals to 1 if a firm becomes publicly traded at some point in its life and zero otherwise. PostIPO_1 to5 is an indicator variable that equals to one for firm-years that are within the first five years following the IPO and zero otherwise. PostIPO_5+ is an indicator variable that equals to one for firm-years that are five years after the IPO date and zero otherwise. DS measures the industry-level (3-digit SIC) demand shock constructed based on changes of shipment from vertical industries. CS measures the annual credit spread using the difference in rates between the A3 and Baa rated-bonds. $\log (\mathrm{Emp})$ is the logarithm of firm employment. $\log (\mathrm{Wage})$ is the logarithm of firm's average wage. Age measures firm's age following birth. All dependent variables are lagged. Industryies are defined using the 3-digit SIC codes. Robust standard errors are clustered at the industry-year level and are reported in parentheses. *, **, and *** represent significance at the $10 \%, 5 \%$, and $1 \%$ level, respectively.

\begin{tabular}{|c|c|c|c|c|c|c|}
\hline Dep Var: Internal Growth & $\begin{array}{c}(1) \\
\text { All Years }\end{array}$ & $\begin{array}{c}(2) \\
\operatorname{Yr}(-5,-1)\end{array}$ & $\begin{array}{c}(3) \\
\operatorname{Yr}(1,5)\end{array}$ & $\begin{array}{c}(4) \\
\operatorname{Yr}(6,10)\end{array}$ & $\begin{array}{l}(5) \\
\mathrm{FE}\end{array}$ & $\begin{array}{l}\text { (6) } \\
\mathrm{FE}\end{array}$ \\
\hline Pub & $\begin{array}{c}0.053 \text { ** } \\
(0.025)\end{array}$ & $\begin{array}{l}0^{0.221} 1^{* * *} \\
(0.031)\end{array}$ & $\begin{array}{l}-0.001 \\
(0.039)\end{array}$ & $\begin{array}{c}-0.134 * \\
(0.074)\end{array}$ & $\begin{array}{r}0.010 \\
(0.033)\end{array}$ & \\
\hline PostIPO_1to5 & & & & & & $\begin{array}{r}0.044 \\
(0.040)\end{array}$ \\
\hline PostIPO_5+ & & & & & & $\begin{array}{l}-0.117 \text { ** } \\
(0.059)\end{array}$ \\
\hline DS & & & & & $\begin{array}{r}0.123 \\
(0.015)\end{array}$ & $\begin{array}{r}0.146 \\
(0.116)\end{array}$ \\
\hline Pub x DS & $\begin{array}{l}0.295 \text { ** } \\
(0.139)\end{array}$ & $\begin{array}{r}-0.083 \\
(0.225)\end{array}$ & $\begin{array}{l}0.482 \text { *** } \\
(0.165)\end{array}$ & $\begin{array}{r}0.470 \\
(0.301)\end{array}$ & $\begin{array}{l}0.5022^{* * *} \\
(0.148)\end{array}$ & \\
\hline $\begin{array}{l}\text { (PostIPO_1to5) x DS } \\
(\text { PostIPO_5+) x DS }\end{array}$ & & & & & & $\begin{array}{c}0.394 * * \\
(0.169) \\
0.562 * \\
(0.321)\end{array}$ \\
\hline Pub x CS & $\begin{array}{l}0.057^{* *} \\
(0.025)\end{array}$ & $\begin{array}{r}-0.003 \\
(0.025)\end{array}$ & $\begin{array}{r}0.062 \\
(0.042)\end{array}$ & $\begin{array}{r}0.088 \\
(0.074)\end{array}$ & $\begin{array}{r}0.043 \\
(0.032)\end{array}$ & \\
\hline $\begin{array}{l}\text { (PostIPO_1to5) x CS } \\
(\text { PostIPO_5+) x CS }\end{array}$ & & & & & & $\begin{array}{r}0.041 \\
(0.041) \\
0.076 \\
(0.055)\end{array}$ \\
\hline Log(Emp) & $\begin{array}{l}-0.028^{* * *} \\
(0.003)\end{array}$ & $\begin{array}{l}-0.057^{* * *} \\
(0.005)\end{array}$ & $\begin{array}{r}-0.004 \\
(0.003)\end{array}$ & $\begin{array}{r}0.000 \\
(0.004)\end{array}$ & $\begin{array}{l}-0.023^{* * *} \\
(0.003)\end{array}$ & $\begin{array}{l}-0.022^{* * *} \\
(0.003)\end{array}$ \\
\hline Log(Wage) & $\begin{array}{l}0.183^{* * *} \\
(0.007)\end{array}$ & $\begin{array}{l}0.216^{* * *} \\
(0.012)\end{array}$ & $\begin{array}{l}0.1599^{* * *} \\
(0.008)\end{array}$ & $\begin{array}{l}0.123 \text { *** } \\
(0.008)\end{array}$ & $\begin{array}{l}0.1999^{* * *} \\
(0.007)\end{array}$ & $\begin{array}{l}0.199 \text { *** } \\
(0.007)\end{array}$ \\
\hline Age & $\begin{array}{l}-0.016^{* * *} \\
(0.002)\end{array}$ & $\begin{array}{l}-0.038^{* * *} \\
(0.002)\end{array}$ & $\begin{array}{l}-0.005^{* * *} \\
(0.002)\end{array}$ & $\begin{array}{r}0.002 \\
(0.001)\end{array}$ & $\begin{array}{l}-0.0589 * * * \\
(0.003)\end{array}$ & $\begin{array}{l}-0.065 \text { *** } \\
(0.004)\end{array}$ \\
\hline R-Square & 0.16 & 0.26 & 0.12 & 0.11 & 0.08 & 0.08 \\
\hline Number of Obs. & 80,000 & 27,000 & 37,000 & 16,000 & 80,000 & 80,000 \\
\hline $\begin{array}{l}\text { Industry-Year FE } \\
\text { Year FE }\end{array}$ & Yes & Yes & Yes & Yes & Yes & Yes \\
\hline Firm-Cohort-Period FE & & & & & Yes & Yes \\
\hline
\end{tabular}




\section{Table 10: Response to Demand Shocks by Public Status and Acquisition Status}

This table presents the estimated coeffcients of regressing firm growth on public status and demand shocks for the matched sample of public and private firms. For each public firm, we select up to 5 matched private firms based on initial conditions and survivial up to the IPO year. The dependent variable is the growth of employment for a firm in a specific year. Column 1 includes all firm years (from up to five years before the IPO to up to 10 years after the IPO); column 2 includes firm years from up to five years prior to IPO; column 3 includes firm years that are up to five years following the IPO; and column 4 includes firm years that are between 6 and 10 years following the IPO. Pub is an indicator that equals to 1 if a firm becomes publicly traded at some point in its life and zero otherwise. Prv Acq Prv is an indicator that equals to 1 if a firm never went public and was acquired by another private firm later in life and zero otherwise. Prv Acq_Pub is an indicator that equals to 1 if a firm never went public and was acquired by a public firm later in life and zero otherwise. DS measures the industry-level (3-digit SIC) demand shock constructed based on changes of shipment from vertical industries. CS measures the credit spread using the difference between the A3 and Baa ratedbonds for the year. $\log (\mathrm{Emp})$ is the logarithm of firm employment. Log(Wage) is the logarithm of firm's average wage. Age measures firm's age following birth. All dependent variables are lagged. We control for industry-year fixed effects in all regressions. Industryies are defined using the 3-digit SIC codes. Robust standard errors allow for clustering at the industry-year level and are reported in parentheses. $*, * *$, and $* * *$ represent significance at the $10 \%, 5 \%$, and $1 \%$ level, respectively.

\begin{tabular}{|c|c|c|c|c|}
\hline Dep Var: Firm Growth & $\begin{array}{c}(1) \\
\text { All Years }\end{array}$ & $\begin{array}{c}(2) \\
\operatorname{Yr}(-5,-1)\end{array}$ & $\begin{array}{c}(3) \\
\operatorname{Yr}(1,5)\end{array}$ & $\begin{array}{c}(4) \\
\operatorname{Yr}(6,10)\end{array}$ \\
\hline Prv Acq_Prv & $\begin{array}{l}0.149 * * * \\
(0.028)\end{array}$ & $\begin{array}{l}0.187 * * * \\
(0.042)\end{array}$ & $\begin{array}{l}0.091 * * \\
(0.039)\end{array}$ & $\begin{array}{r}0.060 \\
(0.046)\end{array}$ \\
\hline Prv_Acq_Pub & $\begin{array}{l}0.131 * * * \\
(0.043)\end{array}$ & $\begin{array}{l}0.112 * * \\
(0.054)\end{array}$ & $\begin{array}{c}0.129 * \\
(0.070)\end{array}$ & $\begin{array}{r}0.122 \\
(0.132)\end{array}$ \\
\hline Pub & $\begin{array}{l}0.124 * * * \\
(0.021)\end{array}$ & $\begin{array}{l}0.237 * * * \\
(0.035)\end{array}$ & $\begin{array}{l}0.099 * * * \\
(0.034)\end{array}$ & $\begin{array}{r}-0.011 \\
(0.039)\end{array}$ \\
\hline Priv_Acq_Prv x DS & $\begin{array}{r}-0.138 \\
(0.152)\end{array}$ & $\begin{array}{l}-0.455 * \\
(0.253)\end{array}$ & $\begin{array}{r}-0.022 \\
(0.197)\end{array}$ & $\begin{array}{r}0.312 \\
(0.336)\end{array}$ \\
\hline Priv_Acq_Pub x DS & $\begin{array}{r}-0.243 \\
(0.236)\end{array}$ & $\begin{array}{r}-0.399 \\
(0.254)\end{array}$ & $\begin{array}{r}0.061 \\
(0.311)\end{array}$ & $\begin{array}{l}-1.566 * \\
(0.847)\end{array}$ \\
\hline Pub x DS & $\begin{array}{l}0.289 * * \\
(0.119)\end{array}$ & $\begin{array}{r}0.018 \\
(0.225)\end{array}$ & $\begin{array}{l}0.483 * * \\
(0.197)\end{array}$ & $\begin{array}{r}0.135 \\
(0.237)\end{array}$ \\
\hline Priv_Acq_Prv x CS & $\begin{array}{l}-0.070 * * \\
(0.028)\end{array}$ & $\begin{array}{l}-0.084 * * \\
(0.042)\end{array}$ & $\begin{array}{r}-0.012 \\
(0.040)\end{array}$ & $\begin{array}{r}-0.060 \\
(0.045)\end{array}$ \\
\hline Priv_Acq_Pub x CS & $\begin{array}{r}0.004 \\
(0.043)\end{array}$ & $\begin{array}{r}0.033 \\
(0.048)\end{array}$ & $\begin{array}{r}-0.005 \\
(0.079)\end{array}$ & $\begin{array}{r}-0.006 \\
(0.120)\end{array}$ \\
\hline Pub x CS & $\begin{array}{r}0.025 \\
(0.019)\end{array}$ & $\begin{array}{r}0.012 \\
(0.028)\end{array}$ & $\begin{array}{r}0.017 \\
(0.033)\end{array}$ & $\begin{array}{r}0.000 \\
(0.033)\end{array}$ \\
\hline $\log (E m p)$ & $\begin{array}{l}-0.039 * * * \\
(0.002)\end{array}$ & $\begin{array}{l}-0.062 * * * \\
(0.005)\end{array}$ & $\begin{array}{l}-0.024 * * * \\
(0.003)\end{array}$ & $\begin{array}{l}-0.006 * \\
(0.003)\end{array}$ \\
\hline Log(Wage) & $\begin{array}{l}0.154 * * * \\
(0.007)\end{array}$ & $\begin{array}{l}0.175 * * * \\
(0.011)\end{array}$ & $\begin{array}{l}0.137 * * * \\
(0.007)\end{array}$ & $\begin{array}{l}0.114^{* * * *} \\
(0.008)\end{array}$ \\
\hline Age & $\begin{array}{l}-0.013 * * * \\
(0.002)\end{array}$ & $\begin{array}{l}-0.035 * * * \\
(0.003)\end{array}$ & $\begin{array}{r}-0.002 \\
(0.002)\end{array}$ & $\begin{array}{r}0.002 \\
(0.001)\end{array}$ \\
\hline $\begin{array}{l}\text { R-Square } \\
\text { Number of Obs. } \\
\text { Industry-Year FE }\end{array}$ & $\begin{array}{r}0.16 \\
89,000 \\
\text { Yes }\end{array}$ & $\begin{array}{r}0.24 \\
30,000 \\
\text { Yes }\end{array}$ & $\begin{array}{r}0.12 \\
42,000 \\
\text { Yes }\end{array}$ & $\begin{array}{r}0.09 \\
18,000 \\
\text { Yes }\end{array}$ \\
\hline
\end{tabular}




\section{Table 11: Response to Demand Shocks by Public Status and Financial Dependence}

This table presents the estimated coeffcients of regressing firm growth on public status, demand shocks, and financial dependence for the matched sample of public and private firms. For each public firm, we select up to 5 matched private firms based on initial conditions and survivial up to the IPO year. The dependent variable is the annual growth rate of employment in a specific year. Pub is an indicator that equals to 1 if a firm becomes publicly traded at some point in its life and zero otherwise. Column 1 includes all firm years (from up to five years before the IPO to up to 10 years after the IPO); column 2 includes firm years from up to five years prior to IPO; column 3 includes firm years that are up to five years following the IPO; and column 4 includes firm years that are between 6 and 10 years following the IPO. PostIPO is an indicato variable that equals to 1 for public years and zero for private firms or public firms prior to the IPO. We include firm-cohort period fixed effects in column 5. FD (Non-FD) is an indicator that equals to 1 if the industry is (not) financially dependent. We measure financial dependence using the difference between capital expenditure and internal operating cash flow over total assets and define FD to be 1 if the median rate of the industry is higher than the median of all industries. DS measures the industry-leve (3-digit SIC) demand shock constructed based on changes of shipment from vertical industries. CS measures the credit spread using the difference between the A3 and Baa rated-bonds for the year.

$\log (\mathrm{Emp})$ is the logarithm of firm employment. $\log ($ Wage $)$ is the logarithm of firm's average wage. Age measures firm's age following birth. All dependent variables are lagged. We control for industry-year fixed effects in all regressions. Industryies are defined using the 3-digit SIC codes. Robust standard errors are clustered at the industry-year level and reported in parentheses. *,**, and *** represent significance at the $10 \%, 5 \%$, and $1 \%$ level, respectively.

\begin{tabular}{|c|c|c|c|c|c|}
\hline Dep Var: Firm Growth & $\begin{array}{c}(1) \\
\text { All Years } \\
\end{array}$ & $\begin{array}{c}(2) \\
\operatorname{Yr}(-5,-1) \\
\end{array}$ & $\begin{array}{c}(3) \\
\operatorname{Yr}(1,5) \\
\end{array}$ & $\begin{array}{c}(4) \\
\operatorname{Yr}(6,10) \\
\end{array}$ & $\begin{array}{l}(5) \\
\mathrm{FE} \\
\end{array}$ \\
\hline Pub x Non-FD & $\begin{array}{l}0.150^{* * *} \\
(0.026)^{*}\end{array}$ & $\begin{array}{l}0.278^{* * *} \\
(0.038)\end{array}$ & $\begin{array}{l}0.167^{* * *} \\
(0.044)^{*}\end{array}$ & $\begin{array}{l}-0.049 \\
(0.068)\end{array}$ & \\
\hline Pub x FD & $\begin{array}{r}0.034 \\
(0.029)\end{array}$ & $\begin{array}{l}0.112 * * \\
(0.048)\end{array}$ & $\begin{array}{r}0.000 \\
(0.044)\end{array}$ & $\begin{array}{r}-0.008 \\
(0.045)\end{array}$ & \\
\hline $\begin{array}{l}\text { PostIPO x Non-FD } \\
\text { PostIPO x FD }\end{array}$ & & & & & $\begin{array}{l}0.127 * * * \\
(0.035) \\
0.028 \\
(0.033)\end{array}$ \\
\hline Pub x Non-FD x DS & $\begin{array}{r}0.120 \\
(0.178)\end{array}$ & $\begin{array}{r}0.094 \\
(0.320)\end{array}$ & $\begin{array}{r}0.103 \\
(0.243)\end{array}$ & $\begin{array}{r}0.283 \\
(0.439)\end{array}$ & \\
\hline Pub x FD x DS & $\begin{array}{l}0.498^{* * *} \\
(0.151)\end{array}$ & $\begin{array}{r}0.183 \\
(0.295)\end{array}$ & $\begin{array}{l}0.694^{* * *} \\
(0.223)^{*}\end{array}$ & $\begin{array}{r}0.098 \\
(0.288)\end{array}$ & \\
\hline $\begin{array}{l}\text { PostIPO x Non-FD x DS } \\
\text { PostIPO x FD x DS }\end{array}$ & & & & & $\begin{array}{l}0.146 \\
(0.217) \\
0.485 \text { *** } \\
(0.157)\end{array}$ \\
\hline Pub x Non-FD x CS & $\begin{array}{r}0.002 \\
(0.024)\end{array}$ & $\begin{array}{r}-0.037 \\
(0.034)\end{array}$ & $\begin{array}{l}-0.062 \\
(0.043)\end{array}$ & $\begin{array}{r}0.018 \\
(0.060)\end{array}$ & \\
\hline Pub x FD x CS & $\begin{array}{l}0.067 \text { ** } \\
(0.028)\end{array}$ & $\begin{array}{l}0.091)^{* * *} \\
(0.038)\end{array}$ & $\begin{array}{l}0.076 * \\
(0.044)\end{array}$ & $\begin{array}{r}-0.001 \\
(0.037)\end{array}$ & \\
\hline $\begin{array}{l}\text { PostIPO x Non-FD x CS } \\
\text { PostIPO x FD x CS }\end{array}$ & & & & & $\begin{array}{r}-0.044 \\
(0.032) \\
0.020 \\
(0.030)\end{array}$ \\
\hline $\log (\mathrm{Emp})$ & $\begin{array}{l}-0.033^{* * *} \\
(0.002)\end{array}$ & $\begin{array}{l}-0.056^{* * *} \\
(0.005)\end{array}$ & $\begin{array}{l}-0.017^{* * *} \\
(0.003)\end{array}$ & $\begin{array}{l}-0.005 * \\
(0.003)\end{array}$ & $\begin{array}{l}-0.026 * * * \\
(0.003)\end{array}$ \\
\hline Log(Wage) & $\begin{array}{l}0.158^{* * *} \\
(0.007)\end{array}$ & $\begin{array}{l}0.179 * * * \\
(0.011)\end{array}$ & $\begin{array}{l}0.141^{* * * *} \\
(0.007)\end{array}$ & $\begin{array}{l}0.115^{* * *} \\
(0.008)\end{array}$ & $\begin{array}{l}0.167 \text { *** } \\
(0.006)\end{array}$ \\
\hline Age & $\begin{array}{l}-0.013^{* * *} \\
(0.002)^{-}\end{array}$ & $\begin{array}{l}-0.035 * * * \\
(0.003)\end{array}$ & $\begin{array}{r}-0.002 \\
(0.002) \\
\end{array}$ & $\begin{array}{r}0.002 \\
(0.001) \\
\end{array}$ & $\begin{array}{l}-0.017^{* * *} \\
(0.001)^{-}\end{array}$ \\
\hline $\begin{array}{l}\text { R-Square } \\
\text { Number of Obs. }\end{array}$ & $\begin{array}{r}0.15 \\
89,000\end{array}$ & $\begin{array}{r}0.23 \\
30,000\end{array}$ & $\begin{array}{r}0.11 \\
42,000\end{array}$ & $\begin{array}{r}0.09 \\
18,000\end{array}$ & $\begin{array}{r}0.10 \\
89,000\end{array}$ \\
\hline $\begin{array}{l}\text { Industry-Year FE } \\
\text { Year FE } \\
\text { Firm-Cohort Period FE }\end{array}$ & Yes & Yes & Yes & Yes & $\begin{array}{l}\text { Yes } \\
\text { Yes }\end{array}$ \\
\hline
\end{tabular}




\section{Table 12: Response to Demand Shocks by Public Status - Matched in 2001}

This table presents the estimated coeffcients of regressing firm growth on public status and demand shocks for the matched sample of public and private firms in 2001 . For each public firm, we select up to 5 matched private firms based on size and age in 2001. The dependent variable is the growth of employment for a firm in a specific year. Panel A presents summary statistics for our subsamples. In Panel B, column 1 include all firm years up to 2010; column 2 - 5 split the sample by firm age - cutoffs are set at 5 , 10 and 20

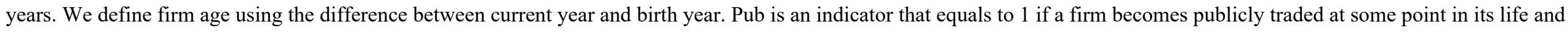

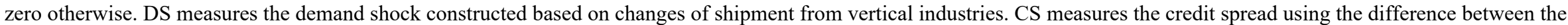

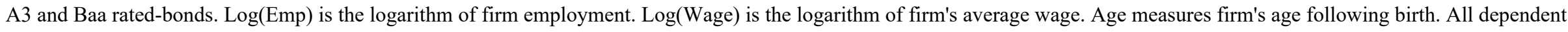
variables are lagged. We control for industry-year fixed effects in all regressions. Industryies are defined using the 3-digit SIC codes. Robust standard error are clustered at the industry-year level and reported in parentheses. *, **, and *** represent significance at the $10 \%, 5 \%$, and $1 \%$ level, respectively.

Panel A: Group Mean for Subsamples used in Matching

\begin{tabular}{|c|c|c|c|c|c|c|c|}
\hline & Total Emp & $\begin{array}{c}\text { Wage } \\
\text { (in } \$ 000)\end{array}$ & Firm Age & Sales/Emp & $\begin{array}{c}\text { Growth } \\
\text { (last } 3 \text { years) }\end{array}$ & $\begin{array}{c}\text { Growth } \\
\text { (next } 3 \text { Years) }\end{array}$ & \# of Firms \\
\hline Public Unmatched & 25703 & 45 & 21 & 10768 & 0.084 & 0.011 & 550 \\
\hline Public Matched & 2479 & 62 & 17 & 2666 & -0.104 & -0.099 & 5,800 \\
\hline Private Matched & 1343 & 43 & 17 & 1553 & 0.037 & -0.008 & 26,600 \\
\hline Private Unmatched & 22 & 29 & 12 & 135 & 0.000 & 0.000 & $1,559,500$ \\
\hline
\end{tabular}

Panel B: Firm Growth

\begin{tabular}{|c|c|c|c|c|c|}
\hline & (1) & (2) & (3) & (4) & (5) \\
\hline & All Years & Age $=(1,5)$ & Age $=(6,10)$ & Age $=(11,20)$ & Age $>20$ yrs \\
\hline \multirow[t]{2}{*}{ Pub } & $-0.031 * *$ & -0.190 & -0.094 & -0.020 & -0.006 \\
\hline & $(0.013)$ & $(0.146)$ & $(0.060)$ & $(0.030)$ & $(0.011)$ \\
\hline \multirow[t]{2}{*}{ Pub * DS } & $-0.226 *$ & 0.365 & -0.055 & $-0.606 *$ & -0.173 \\
\hline & $(0.131)$ & $(1.003)$ & $(0.490)$ & $(0.310)$ & $(0.111)$ \\
\hline \multirow[t]{2}{*}{ Pub * CS } & -0.008 & 0.034 & -0.030 & $-0.044 *$ & -0.012 \\
\hline & (0.009) & $(0.138)$ & $(0.049)$ & $(0.023)$ & $(0.008)$ \\
\hline \multirow[t]{2}{*}{ Log(Emp) } & 0.000 & -0.021 & 0.004 & $0.003 *$ & 0.000 \\
\hline & $(0.001)$ & $(0.014)$ & $(0.004)$ & $(0.002)$ & $(0.001)$ \\
\hline \multirow[t]{2}{*}{ Log(Wage) } & $0.059 * * *$ & $0.089 * * *$ & $0.088 * * *$ & $0.074 * * *$ & $0.041 * * *$ \\
\hline & $(0.005)$ & $(0.019)$ & $(0.010)$ & $(0.006)$ & $(0.006)$ \\
\hline \multirow[t]{2}{*}{ Age } & $0.001 * *$ & 0.007 & -0.003 & $0.002 *$ & -0.001 \\
\hline & $(0.000)$ & $(0.007)$ & $(0.004)$ & $(0.001)$ & $(0.001)$ \\
\hline R-Square & 0.06 & 0.14 & 0.11 & 0.09 & 0.07 \\
\hline \# of Obs. & 171,000 & 7,000 & 13,000 & 35,000 & 115,000 \\
\hline Industry-Year FE & Yes & Yes & Yes & Yes & Yes \\
\hline
\end{tabular}

